\title{
Antiangiogenic therapy for breast cancer
}

\author{
Dorte Lisbet Nielsen ${ }^{1 *}$, Michael Andersson², Jon Lykkegaard Andersen', Claus Kamby ${ }^{1}$
}

\begin{abstract}
Angiogenesis is an important component of cancer growth, invasion and metastasis. Therefore, inhibition of angiogenesis is an attractive strategy for treatment of cancer. We describe existing clinical trials of antiangiogenic agents and the challenges facing the clinical development and optimal use of these agents for the treatment of breast cancer. Currently, the most promising approach has been the use of bevacizumab, a humanized monoclonal antibody directed against the most potent pro-angiogenic factor, vascular endothelial growth factor (VEGF). Small molecular inhibitors of VEGF tyrosine kinase activity, such as sorafenib, appear promising. While, the role of sunitinib and inhibitors of mammalian target of rapamycin (mTOR) in breast cancer has to be defined. Several unanswered questions remain, such as choice of drug(s), optimal duration of therapy and patient selection criteria.
\end{abstract}

\section{Introduction}

Angiogenesis is a pivotal component of cancer growth, including invasion and metastasis. Tumours induce blood vessel growth (angiogenesis) by secreting various growth factors (for example, vascular endothelial growth factor (VEGF)). Growth factors, such as basic fibroblast growth factor and VEGF, can induce capillary growth into the tumour, which allows tumour expansion. Thus, angiogenesis is a necessary and required step for transition from a small harmless cluster of cells to a large tumour and is also required for the spread of a tumour, invasion and/or metastasis. The inhibition of angiogenesis is emerging as a new, attractive therapeutic approach to control tumour progression [1]. At present, several antiangiogenic therapies are in clinical trials testing their promise in breast cancer. This review focusses on clinical aspects of treatment of breast cancer with monoclonal antibodies, and tyrosine kinase and mammalian target of rapamycin (mTOR) inhibitors. In addition, new pivotal angiogenic pathways, such as the Notch ligand Delta-like 4 pathway, are briefly reviewed.

\section{Methods}

The data were obtained by searching in the PubMed database. The search terms used included 'antiangiogenic therapy', 'targeted therapy' and '(metastatic) breast cancer'. In addition, specific drugs (for example, bevacizumab,

\footnotetext{
* Correspondence: dornie01@heh.regionh.dk

'Department of Oncology, Herlev Hospital, University of Copenhagen, Herlev Ringvej 75, DK-2730 Herlev, Denmark

Full list of author information is available at the end of the article
}

sunitinib, and temsirolimus) were included in the search. Our primary focus was phase II and III trials, as only very few phase III trials were identified. Full articles were obtained and references were checked for additional information when appropriate. Proceedings from conferences of the American Society of Clinical Oncology (ASCO), the American Association of Cancer Research (2005 to 2009), and the San Antonio Breast Cancer Symposium (2005 to 2009) were searched for relevant abstracts. Data were updated through July 2010.

\section{Antiangiogenic therapy}

In situ hybridization studies have demonstrated expression of VEGF mRNA in many human tumours, including breast cancer. Thus, VEGF appears to be one of the key players, and current antiangiogenic strategies have therefore mainly aimed at blocking the action of VEGF. Such inhibition can be achieved by direct targeting of the ligand (VEGF) at the mRNA or protein level, direct targeting of its receptors (VEGFR1, VEGFR2, and neuro-pilin-1), or by blocking components of the downstream signaling pathway $[2,3]$.

\section{Inhibitors of VEGF: monoclonal antibodies Bevacizumab in metastatic breast cancer}

Bevacizumab (Avastin'; Genentech Inc., San Francisco, CA, USA; Hoffmann-La Roche Ltd, Basel, Switzerland) is a recombinant humanized monoclonal antibody that binds VEGF and prevents it from binding to its receptors [4]. A phase I/II study of bevacizumab monotherapy in patients with previously treated metastatic breast 
cancer (MBC) has shown a response rate (RR) of $7 \%$ with a median duration of 5.5 months (range 2.3 to 13.7 months); at tumour assessment on day $154,16 \%$ of the patients had stable disease (SD) or an ongoing response [5]. Clinical studies indicate that the anti-neoplastic activity of bevacizumab as monotherapy is modest. Table 1 summarises the results from phase II trials utilizing bevacizumab in combination with chemotherapy, many of which are still preliminary. In these studies, bevacizumab was given as both first-line and later lines of therapy but the results were not always reported separately [6-18]. A first- and second-line phase II trial of bevacizumab in combination with docetaxel demonstrated a RR of $52 \%$ and median progression-free survival (PFS) of 7.5 months [6]. Furthermore, results from a phase II study of bevacizumab plus capecitabine as firstline therapy revealed encouraging results with an $81 \%$ clinical benefit rate (CBR; 6\% complete response (CR), $33 \%$ partial response (PR) and 43\% SD (duration not reported)) [15]. In contrast, a phase II trial of pegylated liposomal doxorubicin and bevacizumab had to be stopped prematurely because of toxicity (including one cardiac toxicity grade 4). The efficacy was modest with an RR of $23 \%$ and a median PFS of 7.5 months [18].

Results of phase III trials comparing chemotherapy regimens with and without bevacizumab are given in
Table 2. A phase III study involving 462 patients with heavily pretreated $\mathrm{MBC}$ was rather disappointing. Adding bevacizumab to capecitabine did not improve the primary endpoint PFS (4.8 versus 4.2 months; hazard ratio $=0.98 ; 95 \%$ confidence interval, 0.77 to 1.25 ) or overall survival (OS; 15.1 versus 14.5 months), despite a doubling in objective RR in the combination arm compared with the capecitabine arm (20 versus 9\%) [19]. This lack of benefit raises several questions about the mechanisms of antiangiogenic therapy (see the Discussion section).

A phase III trial (E2100) including 722 patients (90\% human epidermal growth factor receptor 2 (HER2)negative) randomised to first-line treatment with paclitaxel or paclitaxel plus bevacizumab has been completed. Analysis revealed increased RR (21 versus 37\%, $P<0.001)$ and a doubling in median PFS (5.9 versus 11.8 months, $P<0.001)$ [20]. The OS, however, was similar in the two groups (25.2 versus 26.7 months, $P=0.16$ ). Data on treatment administered after progression were not collected in this trial, precluding an exploratory analysis of the influence of subsequent therapy on OS.

More recently, results from a phase III trial (AVADO) including 736 patients randomised to first-line treatment with docetaxel plus placebo or docetaxel plus bevacizumab (two doses) has been reported. Analysis revealed

Table 1 Phase II trials of bevacizumab in combination with chemotherapy in metastatic breast cancer

\begin{tabular}{|c|c|c|c|c|}
\hline Reference & Number of patients & Therapy & ORR (\%) & $\begin{array}{c}\text { PFS } \\
\text { (months) }\end{array}$ \\
\hline Ramaswamy et al. [6] & 27 (78\% HER2-negative) & $B+$ docetaxel & $52(1 \mathrm{st}+2 \mathrm{nd}$ line $)$ & 8 \\
\hline Chan et al. [7] & 43 (21 evaluable) & B + docetaxel & Approximately 40 (1st line) & $N R$ \\
\hline Hurvitz et al. [8] & $\begin{array}{c}69 \text { (67 evaluable; HER2- } \\
\text { negative) }\end{array}$ & B + docetaxel & 48 (1st line) & $8(\Pi T P)$ \\
\hline \multirow[t]{2}{*}{ Perez et al. [9] } & 45 (HER2-negative) & B + docetaxel + capecitabine & 49 (1st line) & 11 \\
\hline & & & 69 (CBR) & \\
\hline \multirow[t]{2}{*}{ Hoelzer et al. [10] } & 61 (57 evaluable) & B + paclitaxel & 42 (1st line) & 15 \\
\hline & 58 (54 evaluable) & $\mathrm{B}+$ paclitaxel + gemcitabine & 48 & 20 \\
\hline Guardino et al. [11] & 21 (17 evaluable) & $\mathrm{B}+$ paclitaxel + gemcitabine & 88 (CBR) & $N R$ \\
\hline \multirow[t]{3}{*}{ Rugo et al. [12] } & 46 & B + ixabepilone (weekly) & 50 (1st line) & $N R$ \\
\hline & 45 & $B+$ ixabepione $(q 3 w)$ & 71 & $N R$ \\
\hline & 32 & B + paclitaxel & 56 & $N R$ \\
\hline Danso et al. [13] & $\begin{array}{c}49 \text { (27 evaluable; HER2- } \\
\text { negative) }\end{array}$ & B + nab-paclitaxel & 30 (1st line) & 9 \\
\hline \multirow[t]{3}{*}{ Conlin et al. [14] } & 72 & $\begin{array}{l}\text { B + nab-paclitaxel (three dosing } \\
\text { schedules) }\end{array}$ & 42 (1st line) & $9(\Pi \mathrm{TP})$ \\
\hline & 54 & & 42 & 6 \\
\hline & 76 & & 42 & 8 \\
\hline Sledge et al. [15] & 103 & B + capecitabine & 39 (1st line) & $N R$ \\
\hline Traina et al. [16] & 29 & B + capecitabine & $\begin{array}{c}31 \text { (various; } 10 \text { pts with SD }>6 \\
\text { months) }\end{array}$ & NR \\
\hline Dellapasqua et al. [17] & 46 & B + capecitabine + cyclophosphamide & 48 (1st to 3rd line) & $10(\mathrm{TTP})$ \\
\hline Rochlitz et al. [18] & 41 & B + pegylated liposomal doxorubicin & 23 (1st line) & 8 \\
\hline
\end{tabular}

Studies with $\geq 15$ evaluable patients are included. $B$, bevacizumab; CBR, clinical benefit rate; NR, not reported; ORR, overall response rate; PFS, progression free survival; pts, patients; $\mathrm{q} 3 \mathrm{w}$, every third week; SD, stable disease; TTP, time to progression. 
Table 2 Phase III trials of bevacizumab in combination with chemotherapy in metastatic breast cancer

\begin{tabular}{|c|c|c|c|c|}
\hline Reference & $\begin{array}{l}\text { Number of } \\
\text { patients }\end{array}$ & Therapy & ORR (\%) & PFS (months) \\
\hline \multirow[t]{2}{*}{ Miller et al. [19] } & 232 & B (15 mg/kg q3w) + capecitabine & $\begin{array}{c}20 \text { (previous anthracycline and } \\
\text { taxane) }\end{array}$ & 5 (TTP) \\
\hline & 230 & Capecitabine & $9(P=0.001)$ & 4 \\
\hline \multirow[t]{2}{*}{ Miller et al. [20] (E2100) } & $\begin{array}{l}368 \text { (347 intent-to- } \\
\text { treat) }\end{array}$ & B (10 mg/kg q2w) + paclitaxel & 37 (1st line) & 12 (TTP) \\
\hline & $\begin{array}{l}354 \text { (326 intent-to- } \\
\text { treat) }\end{array}$ & Paclitaxel & 21 & $6(P<0.001)$ \\
\hline \multirow[t]{3}{*}{ Miles et al. [21] (AVADO) } & 248 & $B(7.5 \mathrm{mg} / \mathrm{kg} \mathrm{q} 3 \mathrm{w})+$ docetaxel & 55 (1st line) & $9(P=0.045)$ \\
\hline & 247 & B (15 mg/kg q3w) + docetaxel & 64 & $10(P<0.001)$ \\
\hline & 241 & Placebo + docetaxel & 46 & 8 \\
\hline \multirow{4}{*}{$\begin{array}{l}\text { Robert et al. [22] } \\
\text { (RIBBON-1) }\end{array}$} & 409 & B $(15 \mathrm{mg} / \mathrm{kg}$ q3w) + capecitabine & 35 (1st line) & $10(P=0.0011)$ \\
\hline & 206 & Capecitabine & 24 & 6 \\
\hline & 415 & $\begin{array}{l}\text { B }(15 \mathrm{mg} / \mathrm{kg} \mathrm{q} 3 \mathrm{w})+\text { taxane or anthracycline- } \\
\text { based therapy }\end{array}$ & 51 & $11(P=0.040)$ \\
\hline & 207 & Taxane or anthracycline-based therapy & 38 & 8 \\
\hline \multirow[t]{2}{*}{$\begin{array}{l}\text { Brufsky et al. }[24,25] \\
\text { (RIBBON-2) }\end{array}$} & 684 & $\begin{array}{l}\text { B + chemotherapy (capecitabine, gemcitabine, } \\
\text { vinorelbine) }\end{array}$ & 40 (2nd line) & $7(P=0.0072)$ \\
\hline & & Chemotherapy & 30 & 5 \\
\hline
\end{tabular}

B, bevacizumab; ORR, overall response rate; PFS, progression free survival; q2w, every second week; q3w, every third week; TTP, time to progression.

significantly increased RR (46\% versus $55 \%$ versus $64 \%$, respectively) and PFS (8.2, 9.0 and 10.1 months, respectively), though seemingly to a lesser extent than when combined with weekly paclitaxel [21]. OS was similar in all treatment arms with median values of approximately 31 months.

The phase III trial (RIBBON-1) evaluated first-line chemotherapy (anthracycline-based, taxane or capecitabine) with or without bevacizumab. Among 1,237 patients, the addition of bevacizumab to chemotherapy resulted in an improvement in RR and PFS; however, no significant OS advantage was seen [22]. Thus, although these trials have demonstrated significant improvements in RR and PFS, findings to date have not indicated substantial benefit in terms of survival. Recently, a meta-analysis of PFS and OS data from the three abovementioned trials (E2100, AVADO, RIBBON-1) including 2,447 patients has been published. Pooled results for PFS showed an improved median PFS (6.7 to 9.2 months; $P<0.0001$ ) for the bevacizumab-arm whereas pooled results for OS showed no statistically significant difference between the arms (26.4 versus 26.7 months). However, 1-year survival was greater in the bevacizumab arm (82 versus $77 \% ; P=0.003$ ) [23].

Bevacizumab in combination with second-line standard chemotherapy (taxane, gemcitabine, capecitabine, or vinorelbine) has been evaluated in a phase III trial including 684 HER2-negative patients (RIBBON-2). The addition of bevacizumab improved the median PFS (5.1 to 7.2 months; hazard ratio $=0.78 ; P=0.0072)$. Subgroup analyses showed that PFS was consistently improved in the bevacizumab arms across all chemotherapy cohorts [24,25].

Preclinical studies have suggested that oestrogen modulates VEGF-induced angiogenesis. It has been hypothesised that adding bevacizumab to hormonal therapy could reverse required endocrine resistance. MBC patients who had progressed on hormonal therapy after a previous response were included in a phase II trial in which bevacizumab was added to the anti-hormonal therapy. Results from this study (27 patients) showed no responses but SD in $66 \%$ of the patients (duration not reported) [26]. A phase II trial of bevacizumab plus letrozole in 32 postmenopausal women with hormonereceptor-positive advanced breast cancer $(A B C)$ revealed 2 patients with PR and 13 with SD for 6 months or more [27]. Preliminary results from a two arm noncomparative phase II study of bevacizumab combined with anastrozole (25 patients) or fulvestrant (17 patients) as first-line therapy in $\mathrm{MBC}$ reported promising results with a PR rate of $24 \%$, a SD rate of $57 \%$, a median PFS of 16.3 months for the anastrozole arm, and median PFS not reached in the fulvestrant arm [28]. A similar phase II study of bevacizumab plus fulvestrant in 
$33 \mathrm{MBC}$ patients previously treated with an aromatase inhibitor did not meet its statistical endpoint, as only $22 \%$ ( $11 \%$ PR $+11 \%$ SD $\geq 6$ months) of the patients achieved clinical benefit with a median PFS of 6.2 months [29].

\section{Bevacizumab in early-stage breast cancer: preoperative therapy}

Results of phase II trials are given in Table 3 [30-38]. No phase III trials have been reported. A placebo controlled double-blind randomised phase II trial investigated neoadjuvant bevacizumab or placebo followed by docetaxel, doxorubicin, and cyclophosphamide with or without bevacizumab in patients with stage II or III HER2-negative breast cancer. Of 37 patients, 95\% obtained objective responses, including 59\% with CR. The complete pathological response (pCR) rate has not been reported. Congestive heart failure (CHF) grade 3 was reported in three patients and four patients had a decline in left ventricular ejection fraction $>15 \%$; the incidence was similar in the different treatment arms [30]. A phase II study of bevacizumab in combination with docetaxel and cyclophosphamide followed by doxorubicin has shown 38\% pCR in the breast and 29\% in the breast and axilla among 36 patients. However, one patient died of bilateral pulmonary embolism and one developed CHF [31]. In contrast, no CR was reported in
21 patients with inflammatory or locally advanced breast cancer after preoperative treatment with bevacizumab, doxorubicin and docetaxel [34].

Preliminary results from a study evaluating bevacizumab plus letrozole in the preoperative setting has demonstrated an $18 \%$ pCR rate and a $74 \%$ overall response rate (ORR) among 22 postmenopausal, hormone-receptor-positive, HER2-negative patients [39].

\section{Bevacizumab in early-stage breast cancer: adjuvant therapy}

It has been hypothesised that the most beneficial use of antiangiogenic agents would be in the adjuvant setting. However, concern exists about potential cardiac toxicities, including CHF, particularly in patients receiving bevacizumab in combination with anthracyclines. E2104 is a non-randomised trial designed to evaluate the safety of incorporating bevacizumab in anthracycline-containing adjuvant therapy. Patients with lymph node-positive breast cancer were sequentially assigned to adjuvant chemotherapy consisting of dose dense doxorubicin and cyclophosphamide followed by paclitaxel in combination with bevacizumab (26 doses given every second week; 104 patients) or the same treatment but with sequential treatment with bevacizumab (bevacizumab initiated concurrently with paclitaxel; 122 patients) (Table 4) [40]. After a median follow-up of 15 and 11 months,

Table 3 Trials of bevacizumab in early-stage breast cancer: preoperative therapy

\begin{tabular}{|c|c|c|c|c|}
\hline Reference & Phase & Number of patients & Treatment & Response rate (\%) \\
\hline \multirow[t]{4}{*}{$\begin{array}{l}\text { Hurvitz } \\
\text { et al. [30] }\end{array}$} & $\begin{array}{c}\| \\
\text { (randomised) }\end{array}$ & $\begin{array}{l}37 \text { of } 90 \text { planned (HER2- } \\
\text { negative) }\end{array}$ & $\mathrm{A}: \mathrm{TAC}+\mathrm{B}(7.5 \mathrm{mg} / \mathrm{kg})$ & $\begin{array}{l}\text { All regimens: RR 95; CR } \\
\text { 59; PR } 35\end{array}$ \\
\hline & & & B: TAC + placebo & A: PR 58; CR 42 \\
\hline & & & $C: T A C+B(15 \mathrm{mg} / \mathrm{kg})$ & $B+D: P R 27 ; C R 64$ \\
\hline & & & D: TAC + placebo (2:1:2:1, randomisation) & D: PR 21; CR 71 \\
\hline $\begin{array}{l}\text { Makhoul } \\
\text { et al. [31] }\end{array}$ & $\|$ & 36 (11 HER2-negative) & $\begin{array}{l}\text { Bevacizumab }+ \text { docetaxel }+ \text { cyclophosphamide ( } 4 \text { cycles) } \rightarrow \\
\text { doxorubicin ( } 4 \text { cycles) } \rightarrow \text { bevacizumab (adjuvant, } 9 \text { cycles) }\end{array}$ & $\begin{array}{l}\text { PR 31; CR 39; pCR breast } \\
\text { 38; pCR breast }+ \text { axilla } 29\end{array}$ \\
\hline $\begin{array}{l}\text { Greil et al. } \\
{[32]}\end{array}$ & $\|$ & 18 (HER2-negative) & Bevacizumab $\times 5^{*}+($ docetaxel + capecitabine $) \times 6^{*}$ & $\mathrm{pCR} 22$ \\
\hline $\begin{array}{l}\text { Balduzzi } \\
\text { et al. [33] }\end{array}$ & $\|$ & 30 & $\begin{array}{l}\text { Epirubicin }+ \text { cisplatin }+ \text { fluorouracil } \times 4^{*} \rightarrow \text { bevacizumab }+ \\
\text { paclitaxel } \times 3^{*}\end{array}$ & pCR 33; CR + PR 87 \\
\hline $\begin{array}{l}\text { Wedam } \\
\text { et al. [34] }\end{array}$ & $\|$ & 21 (81\% HER2-negative) & $\begin{array}{l}\text { Bevacizumab } \times 1^{*} \rightarrow \text { bevacizumab }+ \text { doxorubicin }+ \\
\text { docetaxel } \times 6^{*}\end{array}$ & PR 67; CR 0 \\
\hline $\begin{array}{l}\text { Lyons } \\
\text { et al. [35] }\end{array}$ & $\|$ & $\begin{array}{l}49 \text { (number of patients } \\
\text { receiving bevacizumab not } \\
\text { reported) }\end{array}$ & Docetaxel + bevacizumab or docetaxel & CR 14; PR 65 \\
\hline $\begin{array}{l}\text { Raefsky } \\
\text { et al. [36] }\end{array}$ & $\|$ & 25 & $\begin{array}{l}\text { Nab-paclitaxel }+ \text { carboplatin } \times 6^{*}+\text { trastuzumab }+ \\
\text { bevacizumab } \times 23^{*}\end{array}$ & PCR 26; PR 16 \\
\hline \multirow[t]{2}{*}{$\begin{array}{l}\text { Locatelli } \\
\text { et al. [37] }\end{array}$} & $\begin{array}{c}\| \\
\text { (randomised) }\end{array}$ & $\begin{array}{c}23 \text { (19 evaluable; locally } \\
\text { advanced) }\end{array}$ & $\mathrm{B} \rightarrow$ vinorelbine + capecitabine (9 pts) & $N R$ \\
\hline & & & B + vinorelbine + capecitabine (14 pts) & NR \\
\hline $\begin{array}{l}\text { Torrisi } \\
\text { et al. [38] }\end{array}$ & $\|$ & $\begin{array}{l}37 \text { (36 evaluable; estrogen } \\
\text { and/or progesterone positive) }\end{array}$ & Bevacizumab + capecitabine + vinorelbine + letrozole & RR 86; pCR 0 \\
\hline
\end{tabular}

Studies with $\geq 15$ evaluable patients are included. B, bevacizumab, in combination with chemotherapy preoperatively plus adjuvant for 52 weeks; $C R$, complete response; NR, not reported; $\mathrm{PCR}$, pathological complete response; PR, partial response; pts, patients; RR, response rate; TAC, docetaxel, doxorubicin, cyclophosphamide (six cycles preoperatively). ${ }^{*}$ Times of treatment. 
Table 4 Trials of bevacizumab in early-stage breast cancer: adjuvant therapy

\begin{tabular}{|c|c|c|c|c|c|c|}
\hline Reference & Phase & Number of patients & Treatment & $\begin{array}{l}\text { Clinical } \\
\text { CHF }\end{array}$ & $\begin{array}{l}\text { LVEF } \\
<40 \%\end{array}$ & DFS \\
\hline \multirow[t]{2}{*}{ Miller et al. [40] } & $\begin{array}{l}\text { "I (two-arm non- } \\
\text { randomised) }\end{array}$ & 104 & $\mathrm{~B}^{1}+(\mathrm{ddAC} \rightarrow$ paclitaxel $)$ & 2 & 4 & NR \\
\hline & & $\begin{array}{l}122 \text { (HER2 status not } \\
\text { reported) }\end{array}$ & $\mathrm{ddAC} \rightarrow \mathrm{B}+$ paclitaxel & 2 & 1 & NR \\
\hline \multirow[t]{3}{*}{ Hart et al. [41] } & Ilb (randomised) & 59 & $\begin{array}{l}\text { HER2-negative randomised: } B^{2}+A C \\
\rightarrow T\end{array}$ & 1 & NR & NR \\
\hline & & 61 & $B^{2}+A C T$ & 2 & NR & NR \\
\hline & & 39 & HER2-positive: $\mathrm{B}^{2}+\mathrm{TCH}$ & 0 & NR & NR \\
\hline Mayer et al. [42] & $\|$ & 40 & $\begin{array}{l}\mathrm{B}^{2}+/ \text { - trastuzumab }+/ \text { - endocrine } \\
\text { therapy }\end{array}$ & 0 & 0 & NR \\
\hline McArthur & $\|$ & 76 & $\mathrm{~B}^{2}+\mathrm{dd} A \mathrm{AC} \times 4 \rightarrow$ nab-paclitaxel $\times 4$ & 0 & 0 & NR \\
\hline
\end{tabular}

et al. [112]

AC, doxorubicin + cyclophosphamide; $A C T$, doxorubicin + cyclophosphamide + docetaxel; $\mathrm{B}^{1}$, bevacizumab $10 \mathrm{mg} / \mathrm{kg}$ every second weeks $\times 26$; $\mathrm{B}^{2}$, bevacizumab15 mg/kg every 3 weeks for a total of 52 weeks; CHF, congestive heart failure; ddAC, dose dense doxorubicin + cyclophosphamide; DFS, diseas-free survival; LVEF, left vntricular ejection fraction; NR, not reported; T, docetaxel; TCH, docetaxel + carboplatin + trastuzumab.

respectively, two patients developed CHF in each arm and declines in left ventricular ejection fraction (LVEF) $<40 \%$ were recorded in four and one patient, respectively. However, only 8 patients completed therapy in the sequential arm, whereas 52 patients completed therapy in the combination arm. No efficacy data have been reported. Hart and colleagues [41] reported preliminary safety data from a randomised phase II study designed to test the feasibility of bevacizumab in combination with three adjuvant docetaxel-containing regimens (Table 4). Three early CHF cases were reported in patients receiving anthracyclines. No cardiac events were identified using the bevacizumab plus trastuzumab combination. A phase II study of adjuvant bevacizumab concomitant with trastuzumab and/or endocrine therapy after neoadjuvant anthracycline-based therapy among 40 patients showed three recurrences within a median follow-up of 8 months. No patient developed CHF [42].

Several studies are ongoing in the adjuvant setting. E5103 is a phase III trial designed to succeed E2104. The trial compares cyclophosphamide, paclitaxel, pegylated liposomal doxorubicin plus placebo with the same combination of chemotherapy plus bevacizumab with the same combination of chemotherapy plus bevacizumab followed by bevacizumab alone. The study is currently recruiting patients (planned enrolment 4,950 patients; NCT00433511). Another phase III trial (BEATRICE) is designed to assess the benefit of adding bevacizumab to standard adjuvant chemotherapy (anthracycline, taxane or combined anthracycline and taxane based regimens). Approximately 3,000 patients with triple-negative breast cancer will be randomised to receive chemotherapy alone or in combination with bevacizumab for a total duration of 12 months (NCT00528567). Finally, the phase III BETH trial evaluates the addition of bevacizumab to adjuvant chemotherapy and trastuzumab in patients with HER2positive breast cancer (estimated enrolment 3,500 patients; NCT00625898).

The tolerability of bevacizumab is generally acceptable, and the drug can readily be administrated in combination with chemotherapeutic agents, which, in some circumstances, may be synergistic. Common adverse events include asthenia, headache, hypertension, proteinuria, diarrhoea, nausea, vomiting, and stomatitis. Most adverse events are mild to moderate and clinically manageable. Serious but rare adverse events include gastrointestinal perforation, wound healing complications, episodes of bleeding, and thrombosis [43].

\section{VEGF trap}

Novel agents targeting VEGF include the VEGF trap aflibercept (developed by Regeneron, Tarrytown, NY, in collaboration with Sanofi-Aventis, Bridgewater, NJ), which is a fully human, soluble fusion protein. The protein construct consist of parts of the extracellular domains of VEGFR1 and VEGFR2 fused to the Fc segment of human IgG1. Aflibercept binds and neutralises all isoforms of VEGF and placental growth factor (PlGF) and is the most potent VEGF blocker available, binding VEGF with 100- to 1,000-fold higher affinity than other reported VEGF antagonists [44]. A phase II study in 21 patients with $\mathrm{MBC}$ previously treated with an anthracycline and/or a taxane reported a 5\% PR rate and did not meet efficacy goals [45].

\section{Antibodies targeting integrins}

The integrins are a family of at least $24 \alpha \beta$ heterodimeric glycoproteins involved in cell matrix binding and communication. The $\alpha_{v}$ integrins are expressed by endothelial cells, particularly during angiogenesis, and are implicated in signal transduction by VEGF, fibroblast 
growth factor, and a variety of other cytokines. Several integrin inhibitors are under development - for example, CNTO 95 (Centocor, Horsham, PA, and Janssen-Cilag Pharmaceutical, SRL), a fully human antibody directed against the $\alpha_{v}$ integrin receptor [46]. We did not identify breast cancer studies.

\section{Anti-placental growth factor antibody}

Recently, the effect of a neutralising murine anti-PIGF antibody, TB-403 (Bioinvent International, Lund, Sweden, and ThromboGenics, Leuven, Belgium; HoffmannLa Roche Ltd, Basel, Switzerland), was reported. Unlike VEGF, PIGF selectively binds VEGFR1 and its co-receptors neuropilin-1 and -2. In vivo, the antibody inhibited the growth and metastasis of various tumours, including those resistant to VEGF inhibitors. Distinct from VEGF inhibitors, TB-403 prevented infiltration of angiogenic macrophages and severe tumour hypoxia, and thus did not switch on the angiogenic rescue program responsible for resistance to VEGF. Potentially, the safety profile of the drug is favourable as it did not affect healthy vessels [47]. The drug is currently being investigated in a phase I trial (NCT00702494).

\section{Inhibitors of other receptors related to angiogenesis: tyrosine kinase inhibitors}

In parallel with the clinical development of bevacizumab, multiple small molecule inhibitors of the VEGF receptor tyrosine kinases have entered the clinic. A huge number of small molecules are in pre-clinical and clinical development (Table 5). Table 6 summarises the results from trials utilising tyrosine kinase inhibitors, many of which are still preliminary.

Sunitinib (Sutent $^{\oplus}$, SU11289; Pfizer, New York, NY, USA) is a multitarget inhibitor with activity against VEGF2, platelet-derived growth factor receptor (PDGFR) $\beta$, stem cell factor receptor (c-Kit) and FLT3 tyrosine kinase signaling pathways [48]. A phase II trial demonstrated $11 \%$ PR and 5\% SD among 64 patients with

$\begin{aligned} & \text { Table } 5 \text { Tyrosine kinase inhibitors targeting the } \\
& \text { angiogenic pathway currently in clinical development in } \\
& \text { breast cancer }\end{aligned}$
\begin{tabular}{ll}
\hline Drug & Target \\
\hline Sunitinib & VEGFR2, PDGFR- $\beta$, FLT3, c-Kit \\
Sorafenib & VEGFR1, 2 and 3, PDGFR- $\beta$, FLT3, c-Kit, Raf \\
Pazopanib & VEGFR1, 2 and 3, PDGFR- $\alpha / \beta, c-K i t$ \\
Vatalanib & VEGF1, 2 and 3, PDGFR, c-Kit, c-Fos \\
Cediranib & VEFGR1, 2 and 3, PDGFR, c-Kit \\
Vandetanib & VEGFR2, EGFR, RETS \\
AMG 706 & VEGFR1, 2 and 3, PDGFR- $\beta$, c-kit \\
Axitinib & VEGFR1, 2 and 3, PDGFR, c-Kit \\
\hline
\end{tabular}

EGFR, epidermal growth factor receptor; PDGFR, platelet-derived growth factor receptor; VEGFR, vascular endothelial growth factor receptor. refractory, late-stage $\mathrm{MBC}$ receiving sunitinib as monotherapy; median time to progression and OS were 10 and 38 weeks, respectively [49]. All phase I/II studies of sunitinib in combination with chemotherapy have shown activity and manageable toxicities [49-53]. However, a phase III study of sunitinib plus paclitaxel versus bevacizumab plus paclitaxel as first-line therapy in ABC (NCT00373256) has been terminated prematurely as it would not have met its primary goal (the primary endpoint being PFS). Furthermore, two phase III studies comparing docetaxel plus sunitinib with docetaxel and capecitabine plus sunitinib with capecitabine did not meet their primary endpoint of prolongation of PFS despite a significantly increased ORR (51\% versus $39 \%$ ) in the docetaxel study [54,55]. Finally, a study comparing capecitabine with sunitinib in $\mathrm{MBC}$ has been halted because of futility [56].

The most important treatment-related serious adverse events have been pulmonary embolism, thrombocytopenia, tumour haemorrhage, febrile neutropenia, and hypertension. The most common treatment-related adverse events include fatigue, gastrointestinal disorders, such as diarrhoea, nausea, stomatitis, dyspepsia and vomiting, hand-foot syndrome, skin decolouration and anorexia. A retrospective review of 75 patients with gastrointestinal tumours receiving sunitinib in phase I/II trials showed $11 \%$ had $\mathrm{CHF}$ after repeated doses of sunitinib. The study underscores the importance of cardiac monitoring [57].

Sorafenib (Nexavar*; Bayer AG Health Care, Leverkusen, Germany, and Onyx Pharmaceuticals, Emeryville, CA, USA) is a multikinase inhibitor that targets Raf kinase and the receptor tyrosine kinases VEGFR 1, 2, and 3, PDGFR $\beta$, c-Kit and FLT3 [58]. A phase II study of 54 pretreated $\mathrm{MBC}$ patients showed one with $\mathrm{PR}$ and 20 with SD (37\%) [59]. The findings reflect those obtained in renal cancer, in which SD has been the main finding. A randomised phase IIb study (229 MBC patients) comparing capecitabine plus sorafenib with capecitabine plus placebo has shown significantly increased PFS [60]. In addition, a randomised phase IIb study comparing paclitaxel plus sorafenib with paclitaxel plus placebo as first-line therapy in $237 \mathrm{MBC}$ patients demonstrated significant improvements in time to progression and ORR. However, the primary endpoint, PFS, was not significantly increased [61] (Table 6). Like sunitinib, sorafenib is associated with fatigue, anorexia, diarrhoea, rash, and hand-foot syndrome.

Pazopanib (Armala', GW786034; GlaxoSmithKline, Middlesex, UK) is a multitarget inhibitor with activity against VEGFR1, 2 and 3 in addition to PDGFR $\alpha / \beta$ and c-Kit [62]. A phase I study of pazopanib alone in MBC revealed one with PR and 11 with SD among 19 patients [63].

Vatalanib (PTK787/ZK 222584; Novartis Institutes for BioMedical Research Oncology, Basel, Switzerland) and 
Table 6 Trials of tyrosine kinase inhibitors targeting the angiogenic pathway in metastatic breast cancer

\begin{tabular}{|c|c|c|c|c|c|}
\hline Reference & Phase & $\begin{array}{l}\text { Number of } \\
\text { patients }\end{array}$ & Treatment & Response (\%) & PFS (months) \\
\hline Burstein et al. [49] & $\|$ & 64 & Sunitinib & $\begin{array}{l}\text { PR 2; SD } \geq 6 \\
\text { months } 8\end{array}$ & 2.5 (TTP) \\
\hline Lyandres et al. [50] & । & 15 & $\begin{array}{l}\text { Sunitinib + cyclophosphamide } \\
+ \text { methotrexate }\end{array}$ & $\begin{array}{l}\text { PR 7; SD }>6 \\
\text { months } 7\end{array}$ & NR \\
\hline Gianni et al. [51] & $\|$ & 13 & Sunitinib + docetaxel & PR 61; SD 23 & NR \\
\hline Kozloff et al. [52] & 1 & 20 & Sunitinib + paclitaxel & CR 10; PR 15 & NR \\
\hline \multirow[t]{2}{*}{ Wildiers et al. [53] } & $\begin{array}{c}\| \\
\text { (randomised) }\end{array}$ & 36 & Taxane $\rightarrow$ sunitinib & NR & 3.4 \\
\hline & & 19 & Taxane $\rightarrow$ no treatment & NR & 3.1 \\
\hline NCT00373256 & III & NR & $\begin{array}{l}\text { Paclitaxel + sunitinib Paclitaxel } \\
+ \text { bevacizumab }\end{array}$ & \multicolumn{2}{|c|}{ Did not meet primary end point (increased PFS) } \\
\hline \multirow[t]{2}{*}{ Bergh et al. [54] } & III & 296 & Docetaxel + sunitinib & 51 & 8.6; OS 24.8 \\
\hline & & 297 & Docetaxel + placebo & 39 & 8.3; OS 25.5 \\
\hline \multirow[t]{2}{*}{ Crown et al. [55] } & III & 221 & Capecitabine + sunitinib & 19 & $5.5 ;$ OS 16.4 \\
\hline & & 221 & Capecitabine & 16 & 5.9; OS 16.5 \\
\hline \multirow[t]{2}{*}{ Barrios et al. [56] } & III & 244 & Sunitinib & 11 & 2.8; OS 15.3 \\
\hline & & 238 & Capecitabine & 16 & $4.2 ;$ OS 24.6 \\
\hline Bianchi et al. [59] & $\|$ & 54 & Sorafenib & $\begin{array}{l}\text { PR } 1 ; \text { SD } \geq 6 \\
\text { months } 37\end{array}$ & NR \\
\hline \multirow[t]{2}{*}{ Baselga et al. [60] } & $\begin{array}{c}\| \\
\text { (randomised) }\end{array}$ & 114 & Capecitabine + sorafenib & NR & $\begin{array}{c}\text { PFS increased }(P=0.0006 \text { versus } \\
\text { Capecitabine }+ \text { placebo })\end{array}$ \\
\hline & & 115 & Capecitabine + placebo & & \\
\hline \multirow[t]{2}{*}{ Gradishar et al. [61] } & $\begin{array}{c}\| \\
\text { (randomised) }\end{array}$ & 119 & Paclitaxel + sorafenib & 67 & $6.9 ;$ ТТР 8.1 \\
\hline & & 118 & Paclitaxel + placebo & 54 & $5.6(P=0.0857) ;$ TTP $5.6(P=0.0171)$ \\
\hline Isaacs et al. [113] & $|/| \mid$ & 35 & Anastrozole + sorafenib & $\begin{array}{c}\text { CBR } 20 \text { (PR }+S D \geq 6 \\
\text { months) }\end{array}$ & $N R$ \\
\hline Taylor et al. [63] & । & 21 & Pazopanib & $\begin{array}{l}\text { PR } 5 ; \text { SD } \geq 6 \\
\text { months } 21\end{array}$ & 3.7 (TTP) \\
\hline Miller et al. [66] & $\|$ & 46 & Vandetanib & SD $\geq 6$ months 2 & $N R$ \\
\hline \multirow[t]{2}{*}{ Boér et al. [67] } & $\begin{array}{c}\| \\
\text { (randomised) }\end{array}$ & 35 & Docetaxel + vandetanib & NR & 9 \\
\hline & & 29 & Docetaxel + placebo & NR & 6 \\
\hline de Boer et al. [69] & । & $\begin{array}{c}13(9 \\
\text { evaluable) }\end{array}$ & $\begin{array}{l}\text { Motesanib diphosphate }+ \\
\text { taxane }\end{array}$ & $\begin{array}{l}\mathrm{PR} 22 ; \mathrm{SD} \geq 6 \\
\text { months } 11\end{array}$ & NR \\
\hline \multirow[t]{2}{*}{ Rugo et al. [71] } & $\begin{array}{c}\| \\
\text { (randomised) }\end{array}$ & 168 & Docetaxel + axitinib & 40 & 8.2 (TTP) \\
\hline & & & Docetaxel & 23 & $7.0(P=0.052)$ \\
\hline
\end{tabular}

CBR, clinical benefit rate; CR, complete response; NR, not reported; ORR, overall response; OS, overall survival; PFS, progression free survival; PR, partial response; pts, patients; SD, stable disease; TTP, time to progression.

cediranib (Recentin ${ }^{\circ}$, AZD2171; AstraZeneca Pharmaceuticals, London, UK) are pan-VEGF, PDGFR, and c-Kit receptor tyrosine kinase inhibitors [64]. No results have yet been published with regard to breast cancer.

Vandetanib (ZD6474; Zactima'; AstraZeneca, London, UK) is a VEGFR2 inhibitor that also has activity against epidermal growth factor and RETS receptor tyrosine kinases [65]. The compound exhibited little activity in MBC [66]. A randomised phase II study of docetaxel plus vandetanib or placebo as second-line therapy in 64 patients with $\mathrm{ABC}$ showed no difference between the two arms [67].
The nicotinamide motesanib diphosphate (AMG 706; Amgen Inc., Thousand Oaks, CA, USA) is a multikinase inhibitor of VEGFR1, 2 and 3, PDGFR and c-Kit [68]. A phase Ib study of motesanib diphosphate in combination with paclitaxel or docetaxel in locally advanced breast cancer is ongoing. Preliminary results have shown that the combinations are tolerable [69].

Axitinib (AG-013736) is a tyrosine kinase inhibitor with activity against VEGFR1, 2 and 3, PDGFR and c-Kit [70]. This agent in combination with docetaxel has been compared to docetaxel in a randomised phase II trial. The addition of axitinib significantly increased 
ORR (40\% versus 23\%) and prolonged time to progression [71].

In general, these above-mentioned trials have shown some activity of tyrosine kinase inhibitors in $\mathrm{MBC}$, although results have been heterogeneous. Thus, phase II randomised trials including sorafenib or axtinib have shown increased PFS $[60,71]$. On the other hand, other trials have been negative $[66,67]$ and accumulated data from recent trials did not support the use of sunitinib in the treatment of MBC [53-56]. The reason for the lack of effect is probably multifactorial. One explanation could be insufficient dose intensity due to toxicity. Furthermore, the patient populations in many of the studies have been heterogeneous and heavily pretreated. For other reasons see the Discussion section. It is possible, however, that drugs like, for example, sunitinib are active within a small, specific subgroup of patients.

\section{$\boldsymbol{\gamma}$-Secretase inhibitors}

The Notch-Delta-like signaling pathway plays an important oncogenic role in breast tumour development in animal models and is probably also significant in human breast tumours. Central to Notch activation is $\gamma$-secretase, which cleaves Notch, allowing its translocation to the nucleus, where it activates target genes. Thus, inhibition of $\gamma$-secretase function would prevent Notch signal transduction [72]. The $\gamma$-secretase inhibitor MK0752 (Merck and Co., Inc., Whitehouse Station, NJ, USA) is currently being evaluated in a phase I/II study.

\section{Inhibition of angiopoietin}

AMG 386 (Amgen Inc., Thousand Oaks, CA, USA) is a fusion protein containing a synthetic peptide exhibiting high affinity for angiopoietins fused to the constant region of human IgG1 [73]. By neutralising angiopoietin 1 and 2, the drug inhibits Tie2-dependent stimulation of endothelial cells. Recent data implicate angiopoietin 2 as an important mediator of the angiogenic process. A phase II placebo-controlled trial in HER2-negative ABC comparing the efficacy of paclitaxel plus AMG 386 versus paclitaxel plus bevacizumab versus paclitaxel in combination with both drugs has been initiated (NCT00511459).

\section{mTOR inhibitors}

mTOR is a serine-threonine protein kinase downstream of the phosphatidylinositol 3-kinase (PI3K)/Akt pathway. This pathway regulates several cellular functions that are critical to tumourigenesis. Evidence suggests that aberrant activation of this pathway plays a major role in breast cancer cell proliferation and in several anti-cancer drug resistance mechanisms. Additionally, mTOR activation increases translation of hypoxia-inducible factor $1 \alpha$ and thereby VEGF [74].
Currently, the mTOR inhibitors temsirolimus (CCI779 (cell-cycle inhibitor)-779; Torisel ${ }^{\circledR}$; Wyeth Pharmaceuticals, Inc., Madison, NJ, USA) [75], everolimus (RAD001, Afinitor; Novartis Institutes for BioMedical Research Oncology, Basel, Switzerland) [76], and ridaforolimus, formerly known as deforolimus (AP23573; ARIAD Pharmaceuticals Inc., Cambridge, MA, USA; MK-8669; Merck and Co., Inc., Whitehouse Station, NJ, USA) [77] are studied in MBC. A phase II randomised study of two dose levels of temsirolimus in 109 patients with previously treated $A B C$ reported an ORR of 9\% (10 with PR) and a CBR of $14 \%$ (SD $\geq 6$ months) [78]. Generally, results have been rather disappointing with a lower-than expected RR (Table 6) [74,79]. Thus, monotherapy with mTOR inhibitors has limited activity in breast cancer (and other cancer types). A potential explanation could be related to a collateral effect of mTOR blockade. Thus, mTOR inhibition blocks the natural negative feed-back on the insulin-like growth factor-1 receptor signaling that inhibits PI3K activation. The result is an increase in PI3K and Akt activation, which could potentially counteract the inhibition of mTOR [80]. The adverse side effects of mTOR inhibitor monotherapy are fatigue, skin rash, stomatitis, increased triglycerides, increased glucose and decreased phosphor. However, these side effects are generally mild. Table 7 summarises trials investigating mTOR inhibitors in MBC.

A phase I trial assessing the combination of everolimus and docetaxel has been terminated as the pharmacokinetic analysis showed variable and unpredictable changes in docetaxel clearance, making the combination unfeasible. No objective response was observed in 15 patients [81]. On the other hand, a phase Ib study of everolimus in combination with cisplatin and paclitaxel was well tolerated with significant antitumour activity (RR 23\%) [82].

Based on the crosstalk between the oestrogen receptor and the PI3K/Akt/mTOR pathway, several clinical trials have explored the combination of an mTOR inhibitor with endocrine therapy. Early data from a randomised three-arm phase II study of temsirolimus in combination with letrozole in 92 postmenopausal women with $\mathrm{ABC}$ has shown clinical activity, with prolonged PFS in the combination arms compared with the letrozole mono-therapy arm [83]. A large phase III study tested temsirolimus combined with letrozole against letrozole alone in 1,112 postmenopausal women with $\mathrm{ABC}$ [84]. The study was terminated prematurely because more grade 3 toxicities were reported with the combination arm. In addition, no improvements in RR or PFS were seen with the combination compared to letrozole alone (RR 27\% in both treatment arms; PFS 8.8 and 8.9 months, respectively). 
Table 7 Trials of mTOR inhibitors in metastatic breast cancer

\begin{tabular}{|c|c|c|c|c|c|}
\hline Reference & Phase & Number of patients & Treatment & Response (\%) & PFS (months) \\
\hline \multicolumn{6}{|c|}{ mTOR inhibitor monotherapy } \\
\hline Chan et al. [78] & ॥ (randomised) & 109 & Temsirolimus (two dose levels) & ORR 9 & NR \\
\hline \multirow[t]{2}{*}{ Ellard et al. [79] } & II (randomised) & 49 (33: daily schedule) & Everolimus (two different schedules) & ORR 12 (daily schedule) & NR \\
\hline & & & ORR 0 (weekly schedule) & NR & NR \\
\hline \multicolumn{6}{|c|}{ mTOR inhibitor plus chemotherapy } \\
\hline Moulder et al. [81]* & 1 & 15 & Everolimus + docetaxel & RR 0 & NR \\
\hline Mayer et al. [82] & $\mathrm{lb}$ & 16 & Everolimus + cisplatin + paclitaxel & RR 23 & NR \\
\hline \multicolumn{6}{|c|}{ mTOR inhibitor plus endocrine therapy } \\
\hline \multirow[t]{3}{*}{ Carpenter et al. [83] } & ॥ (randomised) & 33: daily & Temsirolimus (two schedules) + letrozole & PR 27 & Not reached \\
\hline & & 30: intermittent & & CR 3, PR 27 & Not reached \\
\hline & & 29 & Letrozole & $C R 7+P R 34$ & 9.2 \\
\hline \multirow[t]{2}{*}{ Chow et al. [84]* } & III & 556 & Temsirolimus + letrozole & ORR 27 & 8.8 \\
\hline & & 556 & Letrozole & ORR 27 & 8.9 \\
\hline
\end{tabular}

*Study terminated due to toxicity. CR, complete response; mTOR, mammalian target of rapamycin; NR, not reported; ORR, overall response rate; PFS, progression free survival; PR, partial response; RR, response rate.

Table 8 summarises studies investigating preoperative mTOR inhibitors in early-stage breast cancer. A phase II trial of everolimus monotherapy for 14 days prior to surgery in 30 postmenopausal women with early breast cancer has shown significantly reduced tumour cell proliferation [85]. Furthermore, Baselga and colleagues [86] presented the results of the combination of everolimus plus letrozole in a randomised phase II neoadjuvant trial of 270 oestrogen receptor-positive breast cancer patients. The RR with everolimus plus letrozole was superior to that of placebo plus letrozole (68\% versus $59 \%)$.

\section{Antiangiogenic therapies in combination with other targeting therapies}

Angiogenesis is a complex process composed of multiple signaling pathways. Many of these pathways are redundant, with several ligand-receptor combinations resulting in the same eventual downstream events. It is unlikely that tumours are entirely dependent on only one abnormally activated signaling pathway; consequently, treatment with an agent that interferes with a single target may be insufficient. Simultaneous blockade of multiple pathways has become an attractive therapeutic strategy [87]. Table 9 summarises trials using combination targeting therapies.

\section{Bevacizumab plus trastuzumab}

The HER2 gene is overexpressed in 18 to $25 \%$ of all primary breast cancers. Trastuzumab (Herceptin ${ }^{\circ}$; Genentech Inc., San Francisco, CA, and Hoffmann-La Roche Ltd., Basel, Switzerland) is a recombinant, monoclonal humanised murine antibody directed against the extracellular portion of the HER2 protein. The precise mechanism of its anti-tumour action has not been fully elucidated. Several molecular and cellular effects have been observed, including inhibition of HER2 extracellular proteolysis, disruption of downstream cellular pathways, cell-cycle arrest, inhibition of DNA repair, suppression of angiogenesis, and induction of antibodydependent cell-mediated cytotoxicity. Measurements of HER2 and VEGF in primary breast tumour tissue have demonstrated a positive association between HER 2 and VEGF expression [88]. Therefore, the combination of inhibitors against HER2 and VEGF might be a rational treatment strategy for patients with HER2-positive breast cancer. Preliminary results from a phase II trial (50 patients) of trastuzumab plus bevacizumab as firstline treatment in HER2-positive MBC have demonstrated a $48 \%$ RR, including 2 patients with CR [89]. However, 19 cardiac adverse events were reported, one of which was symptomatic (grade 4). Thus, the combination requires stringent cardiac surveillance.

Table 8 Trials of mTOR inhibitors in early-stage breast cancer: preoperative therapy

\begin{tabular}{lcclc}
\hline Reference & Phase & Number of patients & Treatment & Response \\
\hline Macaskill et al. [85] & $\|$ & 30 & Everolimus (14 days prior to surgery) & Reduced cell proliferation \\
Baselga et al. [86] & II (randomised) & 270 & Everolimus + letrozole & RR 68\% \\
& & & Letrozole & $59 \%$ \\
\hline
\end{tabular}

mTOR, mammalian target of rapamycin; RR, response rate. 
Table 9 Antiangiogenic therapy in combination with other targeting therapies

\begin{tabular}{|c|c|c|c|c|c|c|}
\hline \multirow[b]{3}{*}{ Reference } & \multicolumn{6}{|c|}{ Combination } \\
\hline & \multirow[b]{2}{*}{ Chemotherapy } & \multicolumn{3}{|c|}{ Targeting angiogenesis } & \multicolumn{2}{|c|}{ Targeting HER 1 or 2} \\
\hline & & $\begin{array}{l}\text { Monoclonal } \\
\text { antibody }\end{array}$ & $\begin{array}{c}\text { Tyrosine kinase } \\
\text { inhibitor }\end{array}$ & $\begin{array}{c}\text { mTOR } \\
\text { inhibitor }\end{array}$ & $\begin{array}{c}\text { Monoclonal } \\
\text { antibody }\end{array}$ & $\begin{array}{c}\text { Tyrosine kinase } \\
\text { inhibitor }\end{array}$ \\
\hline \multicolumn{7}{|l|}{ Hurvitz et al. [89] } \\
\hline Dickler et al. [90] & & Bevacizumab & & & & Erlotinib \\
\hline Dickler et al. [91] & & Bevacizumab & & & & Lapatinib \\
\hline Blay et al. [92] & & & Sunitinib & & Trastuzumab & \\
\hline Dirix et al. [93] & Docetaxel & & Sunitinib & & Trastuzumab & \\
\hline Slamon et al. [94] & & & Pazopanib & & & Lapatinib \\
\hline O'Regan et al. [95] & Paclitaxel & & & Everolimus & Trastuzumab & \\
\hline Yardley et al. [96] & & & & Ridaforolimus & Trastuzumab & \\
\hline Mayer et al. [97] & & & & Everolimus & & Erlotinib \\
\hline
\end{tabular}

HER, human epidermal growth factor receptor; mTOR, mammalian target of rapamycin.

\section{Bevacizumab plus erlotinib}

Erlotinib (Tarceva ${ }^{\oplus}$; Genentech Inc., San Francisco, CA, USA, and Hoffmann-La Roche Ltd., Basel, Switzerland) is an inhibitor of the HER1 (epidermal growth factor receptor) tyrosine kinase. Results from a phase II trial of the combination of bevacizumab and erlotinib in 38 MBC patients has been disappointing ( 1 with PR and 4 with $\mathrm{SD}>6$ months) [90].

\section{Bevacizumab plus lapatinib}

Lapatinib (Tyverb ${ }^{\circ}$, GW572016; GlaxoSmithKline, Middle-sex, UK) is a dual tyrosine kinase inhibitor of HER1 and HER2. Like trastuzumab, the compound may have angiogenic downstream effects. A phase II study of bevacizumab plus lapatinib in 52 (27 evaluable) patients with HER2- positive MBC showed an ORR of $13 \%$ and a CBR of $34 \%$. The combination was generally well tolerated [91].

\section{Sunitinib plus trastuzumab}

Preliminary results from an ongoing phase II trial in patients with HER2-positive ABC have shown an ORR of $35 \%$ and a CBR of $48 \%$ among 52 patients receiving sunitinib combined with trastuzumab [92]. Furthermore, the combination of sunitinib, trastuzumab, and docetaxel as first-line therapy in 25 women with HER2-positive MBC showed one with CR and 14 with PR [93].

\section{Pazopanib plus lapatinib}

Recently, results from a randomised, phase II study investigating lapatinib alone or in combination with pazopanib as first-line therapy in HER2-positive MBC patients have been presented. A pre-specified interim analysis of 62 patients demonstrated a RR of $44 \%$ after treatment with the combination regimen compared with $30 \%$ after treatment with lapatinib alone [94]. The study underscores that the combination of VEGF- and HER2targeted therapies could result in substantial clinical benefit.

\section{Everolimus/ridaforolimus plus trastuzumab}

A phase I trial including 22 (17 evaluable) patients with trastuzumab-resistant $\mathrm{MBC}$ treated with paclitaxel plus everolimus plus trastuzumab resulted in 5 with PR and 2 with SD $>16$ weeks [95]. In addition, a phase II trial including 22 (14 evaluable) similar patients treated with a combination of ridaforolimus and trastuzumab has shown 2 with PR [96]. Both combinations were well tolerated.

\section{Everolimus plus erlotinib}

A phase Ib study of the combination of everolimus plus erlotinib in 14 patients with $\mathrm{MBC}$ showed that the regimen was well tolerated. However, the authors concluded that the combination was clinically ineffective and did not warrant further testing in breast cancer [97].

\section{Combinations of antiangiogenic therapies \\ Bevacizumab plus sunitinib}

A randomised phase II study of paclitaxel plus bevacizumab versus paclitaxel plus bevacizumab plus sunitinib as first-line therapy in HER2-negative MBC reported a high rate of dose modifications and/or discontinuations of sunitinib due to toxicity. The authors concluded that the combination was not feasible and the study was closed [98].

A phase I study of bevacizumab in combination with sunitinib, sorafenib, erlotinib plus cetuximab, or trastuzumab plus lapatinib has shown that all combinations were tolerable and preliminary evidence of antitumour activity was demonstrated (the bevacizumab plus sunitinib combination was discontinued due to toxicity data from other studies) [99]. 


\section{Discussion}

Antiangiogenic drugs work essentially in combination with chemotherapy. One possible mechanism for this phenomenon is normalisation of the tumour vasculature, thereby increasing the concentration of drug in the tumour [100].

Despite the promising activity of antiangiogenic drugs in preclinical tumour models, targeting VEGF signaling appears to be insufficient to permanently inhibit tumour angiogenesis. The reasons for this are likely to be multiple and complex. Some critical issues that may be, at least in part, responsible for the failures have been suggested. Primarily, the choice of the appropriate molecular target is essential to the ultimate success of a given therapeutic intervention. Thus, patient selection strategies are of paramount importance. The challenge remains to identify markers predicting the effects of antiangiogenic treatment (see 'Biomarkers of angiogenesis and evaluation of response' below). In contrast to renal cell cancer, there is no documented constitutive activation of the VEGF pathway in breast cancer. However, it is possible that drugs targeting this pathway are very effective within a small, specific subgroup of patients.

Most current antiangiogenic therapies are based on inhibition of VEGF functions. However, tumours also produce multiple non-VEGF angiogenic factors, making angiogenesis a complex process composed of multiple signaling pathways, many of which are redundant. Thus, a switch on the angiogenic rescue program is possibly responsible for resistance to VEGF. Preclinical studies have identified four potential mechanisms of resistance: upregulation of basic fibroblast growth factor; overexpression of matrix metalloproteinase-9; increased level of stromal-cell-derived factor $1 \alpha$; and hypoxia-inducible factor $1 \alpha$-induced recruitment of bone-marrow-derived CD45+ myeloid cells $[101,102]$.

Clonal evolution and tumour adaptation may also result in a tumour that is more tolerant to hypoxia and subsequently less dependent on neovascularization. Finally, substantial inherited variability within VEGF and its receptor (VEGFR2) has been demonstrated, making it plausible that a certain subgroup of patients with a specific genotype may derive sustained benefit from VEGF inhibition [103].

\section{Issues regarding the future of antiangiogenic therapy}

The E2100 trial represents the first successful proof-ofconcept trial for antiangiogenic therapy in breast cancer [20]. However, in spite of improvements in RR and PFS, all randomised studies of antiangiogenic therapy in breast cancer have so far failed to demonstrate an impact on OS. This may be the reason why there is not yet general agreement on the use of bevacizumab in MBC.

Numerous challenges remain. Several tyrosine kinase inhibitors and other agents targeting the angiogenic pathway are in development. Their role has to be established. Furthermore, we do not know which combinations of antiangiogenic agents and standard agents (chemotherapy, hormonal, or biological) will prove most effective. The timing of angiogenesis therapy is also a challenge. This includes the optimal sequence of such therapies. Furthermore, questions about the duration of therapy and even dosages are unanswered. For example, therapy in patients with response or stable disease might be beneficial but difficult to justify without definite survival advantages.

There is increasing evidence that targeting of tumour epithelium and pericytes by combined VEGF and PDGFR blockade may facilitate the metastatic process. Thus, recent articles report how malignant tumours escape from antiangiogenic therapy by metastatic dissemination [104]. These findings might have important implications for the potential use of antiangiogenic therapy in the adjuvant setting. On the other hand, no clinical evidence for increases in the malignant potential of tumours was demonstrated in patients with MBC treated with bevacizumab and docetaxel in the phase III AVADO study [21,105].

\section{Biomarkers of angiogenesis and evaluation of response}

Many biomarkers of angiogenesis have been proposed as predictors for response to antiangiogenetic therapy, but none has yet been identified. Pretreatment plasma levels of VEGF have been evaluated in a range of studies. Generally, elevated levels are indicative of poor prognosis, but do not predict response to antiangiogenic therapy, including bevacizumab. Considerable research has been conducted to test the possibility that single-nucleotide polymorphisms in the germ-line involving angiogenesisrelated genes influence the natural history of the disease and its response to treatment. Recently, an association between the VEGF genotype and median OS and severe hypertension has been demonstrated in $\mathrm{MBC}$ patients receiving bevacizumab and paclitaxel (E2100) [103]. Other approaches include measuring microvessel density or circulating endothelial cells. Recently, the topic has been reviewed by Jain and colleagues [106] and Murukesh and colleagues [107]. Molecular markers to monitor the effect of mTOR inhibitors have been identified in preclinical studies showing tumour growth inhibition to correlate with a decrease of pS6K1 and p4EBP1 [68]. However, findings from clinical studies are still too limited to base selection of patients and dose selection on these biomarkers. 
Another challenge is defining reliable markers for clinical efficacy. Although objective change in tumour size remains an important assessment criterion for the treatment of solid tumours, tumour regression rate or RR might be more relevant as surrogate markers for cytotoxic chemotherapy than for targeted biological agents, which are primarily cytostatic. Thus, assessing only lesion size has demonstrated an inherent limitation when evaluating antiangiogenic drugs. In trials including these agents, disease control or time to progression may be more relevant than conventional response evaluation (PR and CR). Functional imaging - for example, dynamic contrast-enhanced magnetic resonance imaging/computer tomography, positron-emission tomography or contrast-enhanced ultrasound - has been included in several studies. The topics have been comprehensively reviewed by Sessa and colleagues [108] and Marcus and colleagues [109].

\section{Cost}

Monoclonal antibodies and tyrosine kinase inhibitors are relatively expensive in comparison with other cancer therapies. Economic evaluations are needed to clarify whether these expensive treatment options are cost effective. In the metastatic setting, where the goal is to improve quality of life and/or delay the time to disease progression, it is not clear whether health care systems can (or should) carry these expenses [110]. Under any circumstances, resource planning will be needed in order to offer these treatments to all suitable patients. Identifying subgroups of patients who will benefit from treatment and avoid administration to patients who are unlikely to respond significantly improve the cost/benefit ratio [111].

\section{Conclusion}

Development of drugs targeting angiogenesis is in progress and so far there is support for the use of the antibody bevacizumab in combination with taxanes (paclitaxel) as first-line therapy in HER2-negative MBC. Targeted therapy is an area of research and possibly represents an important step in the treatment of MBC. Results of ongoing trials and maturation of the published trials will hopefully lead to more precise knowledge, and thus more cost-effective use of recent developments. Identification of predictive biomarkers and improvement of our understanding of molecular mechanisms is crucial.

\section{Abbreviations}

ABC: advanced breast cancer; CBR: clinical benefit rate; CHF: congestive heart failure; CR: complete response; FDA: Food and Drug Administration; HER: human epidermal growth factor receptor; MBC: metastatic breast cancer; mTOR: mammalian target of rapamycin; ORR: overall response rate; OS: overall survival; pCR: pathological response; PDGFR: platelet-derived growth factor receptor; PFS: progression-free survival; PI3K: phosphatidylinositol 3kinase; PIGF: placental growth factor; PR: partial response; RR: response rate; SD: stable disease; VEGF: vascular endothelial growth factor; VEGFR: vascular endothelial growth factor receptor.

\section{Author details}

'Department of Oncology, Herlev Hospital, University of Copenhagen, Herlev Ringvej 75, DK-2730 Herlev, Denmark. ²Department of Oncology, Finsen Centre, Rigshospitalet, University of Copenhagen, Blegdamsvej 9, DK-2100 Copenhagen, Denmark.

\section{Authors' contributions}

Conception and design of manuscript: DLN, MA. Collection and assembly of data: DLN. Data interpretation: DLN, MA, CK, JLA. Final approval of manuscript: DLN, MA, CK, JLA.

\section{Competing interests}

The authors declare that they have no competing interests.

Published: 29 September 2010

\section{References}

1. Harper J, Moses MA: Molecular regulation of tumor angiogenesis: mechanisms and therapeutic implications. EXS 2006, 96:223-268.

2. Schneider BP, Sledge GW Jr: Drug insight: VEGF as a therapeutic target for breast cancer. Nat Clin Pract Oncol 2007, 4:181-189.

3. Jain RK, Duda DG, Clark JW, Loeffler JS: Lessons from phase III clinical trials on anti-VEGF therapy for cancer. Nat Clin Pract Oncol 2006, 3:24-40.

4. Ferrara N, Hillan K, Gerber H-P, Novotny W: Discovery and development of bevacizumab, an anti VEGF antibody for treating cancer. Nat Rev Drug Discov 2004, 3:391-398.

5. Cobleigh MA, Langmuir VK, Sledge GW, Miller KD, Haney L, Nototny WF, Reiman JD, Vassel A: A phase I/II dose-escalation trial of bevacizumab in previously treated metastatic breast cancer. Semin Oncol 2003, 30(5 Suppl 16):117-124.

6. Ramaswamy B, Elias AD, Kelbick NT, Dodley A, Morrow M, Hauger M, Allen J, Roades C, Kendra K, Chen HX, Eckhardt SG, Shapiro CL: Phase II trial of bevacizumab in combination with weekly docetaxel in metastatic breast cancer patients. Clin Cancer Res 2006, 12:3124-3129.

7. Chan D, Allen H, Hu E, Reese D, Patel G, Gottlieb C, Wax A, Sosa J, Slamon D, Kabbinavar F: Phase II study of docetaxel (D) plus bevacizumab (B) in Her2 negative metastatic breast carcinoma. J Clin Oncol 2006, 24(June 20 Supplement):abstract 13047.

8. Hurvitz SA, Kabbinavar FF, Allen HJ, Moroose RL, Chan D, Hagenstad C, Applebaum SH, Patel G, Hu EH, Reese D, Slamon DJ: A phase II trial of docetaxel with bevacizumab as first line therapy for Her2/neu negative metastatic breast carcinoma. Breast Cancer Res Treat 2007, 106(Suppl 1): abstract 4062.

9. Perez EA, Hillman DW, Dentchev T, Le-Lindqwister NA, Geeraerts $L H$, Fitch TR, Liu H, Graham DL, Kananic SP, Gross HM, Patel TA, Palmieri FM, Dueck AC: North Central Cancer Treatment Group (NCCTG) N0432: phase II trial of docetaxel with capecitabine and bevacizumab as first line chemotherapy for patients with metastatic breast cancer. Ann Oncol 2010, 21:269-274.

10. Hoelzer KL, Brufsky A, Hainsworth J, Beck JT, Whorf R, Keaton M, Kroener J, Krill-Jackson E, Hu S, Bromund J: Preliminary results of a randomized phase II study of paclitaxel and bevacizumab \pm gemcitabine as first-line treatment for metastatic breast cancer. J Clin Oncol 2009, 27(15S):abstract 1089.

11. Guardino AE, Chen M, Levy M, Chen M: Phase II trial with gemcitabine, paclitaxel and bevacizumab for the first line treatment of metastatic breast cancer. Cancer Res 2009, 69(Suppl):abstract 6089.

12. Rugo HS, Campone M, Amadori D, Wardley A, Villa E, Conte PF, Mudenda B, McHenry B, Pivot X: Randomized phase II study of weekly versus every-3week ixabepilone plus bevacizumab (ixa/bev) versus paclitaxel plus bev (pac/bev) as first-line therapy for metastatic breast cancer (MBC). J Clin Oncol 2009, 27(15S):abstract 1029.

13. Danso MA, Blum JL, Robert NJ, Krekow L, Rotche R, Smith DA, Richards $P$, Anderson T, Richards DA, O'Shaughnessy J: Phase II trial of weekly nabpaclitaxel in combination with bevacizumab as first-line treatment in 
metastatic breast cancer. J Clin Oncol 2008, 26(May 20 Suppl):abstract 1075.

14. Conlin AK, Hudis CA, Bach A, Moynaha M, Lake D, Forero-Torres A, Wright G, Hackney M, Claws A, Seidman AD: Randomized phase II trial of nanoparticle albumin-bound paclitaxel in three dosing schedules with bevacizumab as first-line therapy for HER2-negative metastatic breast cancer (MBC). J Clin Oncol 2009, 27(15S):abstract 1006.

15. Sledge G, Miller K, Moisa C, Gradisar W: Safety and efficacy of capecitabine (C) plus bevacizumab (B) as first-line in metastatic breast cancer. J Clin Oncol 2007, 25(18S):abstract 1013.

16. Traina TA, Theodoulou M, Dugan U, Feigin K, Patil S, Geneus S, Godfrey L, Norton L, Hudis C: A novel capecitabine dosing schedule combined with bevacizumab is safe and active in patients with metastatic breast cancer: a phase II study. Cancer Res 2009, 69(Suppl 2):abstract 6121.

17. Dellapasqua S, Bertolini F, Bagnardi V, Campagnoli E, Scarano E, Torrisi R, Shaked Y, Mancuso P, Goldhirsch A, Rocca A, Pietri E, Colleoni M: Metronomic cyclophosphamide and capecitabine combined with bevacizumab in advanced breast cancer. J Clin Oncol 2008, 26:4899-4905.

18. Rochlitz C, Spirig C, Ruhstaller T, Suter T, Bühlmann M, Fehr M, Schönenberger A, Lerch S, Mayer M, Zaman K: Bevacizumab and pegylated liposomal doxorubicin as first-line therapy for locally recurrent or metastatic breast cancer: a multicenter, single-arm phase II trial of the Swiss Group for Clinical Cancer Research (SAKK). J Clin Oncol 2009, 27(15S):abstract 1030.

19. Miller KD, Chap LI, Holmes FA, Cobleigh MA, Marcom PK, Fehrenbacher L, Dickler M, Overmoyer BA, Reiman JD, Sing AP, Langmuir V, Rugo HS: Randomized phase III trial of capecitabine compared with bevacizumab plus capecitabine in patients with previously treated metastatic breast cancer. J Clin Oncol 2005, 23:792-799.

20. Miller KD, Wang M, Gralow J, Dickler M, Cobleigh M, Perez EA, Shenkier T, Cella D, Davidson NE: Paclitaxel plus bevacizumab versus paclitaxel alone for metastatic breast cancer. N Engl J Med 2007, 357:2666-2676.

21. Miles DW, Chan A, Dirix LY, Cortes J, Pivot $X$, Tomczak P, Delozier T, Sohn JH, Provencher L, Puglisi F, Harbeck N, Steger GG, Scheeweiss A, Wardley AM, Chlistalla A, Romieu G: Phase III study of bevacizumab plus docetaxel compared with placebo plus docetaxel for the first-line treatment of human epidermal growth factor receptor 2-negative metastatic breast cancer. J Clin Oncol 2010, 28:3239-3247.

22. Robert N, Dieras V, Glaspy J, Brufsky A, Bondarenko I, Lipatov O, Perez E, Yardley D, Zhou X: RIBBON-1: a randomized, double-blind, placebocontrolled, phase III trial of chemotherapy with or without bevacizumab for first-line treatment of HER2-negative locally recurrent or metastatic breast cancer. J Clin Oncol 2009, 27(15S):abstract 1005.

23. O'Shaughnessy J, Miles D, Gray J, Dieras V, Perez EA, Zon R, Cortes J, Zhou X, Phan S, Miller K: A meta-analysis of overall survival data from three randomized trials of bevacizumab (BV) and first-line chemotherapy as treatment for patients with metastatic breast cancer (MBC). J Clin Oncol 2010, 28(15S):abstract 1005.

24. Brufsky A, Bondarenko IN, Smirnov V, Hurvitz SA, Perez EA, Ponovarova O, Vynnychenko I, Swamy R, Mu H, Rivera RR: RIBBON-2: a randomized, double-blind, placebo-controlled, phase III trial evaluating the efficacy and safety of bevacizumab in combination with chemotherapy for second-line treatment of HER2-negative metastatic breast cancer. Cancer Res 2009, 69(Suppl):abstract 42

25. Brufsky A, Rivera RR, Hurvitz SA, Bondarenko IN, Smirnov V, Valero V, Rugo HS, Swamy R, Mu H, Perez EA: Progression-free survival (PFS) in patient subgroups in RIBBON-2, a phase III trial of chemotherapy (chemo) plus minus bevacizumab (BV) for second-line treatment of HER2-negative, locally recurrent or metastatic breast cancer (MBC). J Clin Oncol 2010, 28(15S):abstract 1021

26. Falkson C, Rossman JF, Nabell L, Carpenter J, Forero A, Kim Y, Saleh M: A phase II trial investigating if bevacizumab in combination with hormone therapy reverse acquired estrogen indepence in metastatic breast cancer patients. J Clin Oncol 2009, 27(15S):abstract e12027.

27. Traina TA, Rugo H, Caravelli JF, Yeh B, Panageas K, Bruckner J, Norton L, Park J, Hudis C, Dickler M: Letrozole ( $L$ ) with bevacizumab $(B)$ is feasible in patients (pts) with hormone receptor-positive metastatic breast cancer (MBC). J Clin Oncol 2006, 24(18S):abstract 3050.

28. Rubin MS, Barton J, Shipley D, Arrowsmith E, Peacock N, Hart L, Evans J, Vasquez $E$, Burris HA, Yardley D: Efficacy results from a multicenter phase II noncomparative two-arm pilot trial of bevacizumab with anastrozole or fulvestrant as first-line endocrine therapy for metastatic breast cancer. J Clin Oncol 2009, 27(15S):abstract 1091.

29. Tan WW, Dueck AC, Flynn P, Steen P, Anderson D, Rowland K, Nothfeldt D, Lingle W, Copland J, Perez EA: N0539 Phase II trial of fulvestrant and bevacizumab in patients with metastatic breast cancer previously treated with an aromatase inhibitor: a North Central Cancer Treatment Group trial. Cancer Res 2009, 69(Suppl):abstract 4096.

30. Hurvitz SA, Bosserman LD, Leland-Jones B, Thirwell M, Allison MK, Barstis J, Molthrop D, Quan E, Upadhyaya G, Slamon D: A multicenter, double-blind randomized phase II trial of neoadjuvant treatment with single-agent bevacizumab or placebo, followed by docetaxel, doxorubicin, and cyclophosphamide (TAC), with or without bevacizumab, in patients with stage II or III breast cancer. J Clin Oncol 2008, 26(May 20 Suppl):abstract 562 .

31. Makhoul I, Klimberg S, Henry-Tillman R, Westbrook K, Korourian S, Siegel E, Hutchins L: Primary systemic therapy using docetaxel/ cyclophosphamide/bevacizumab (TCB) followed by doxorubicin (A) in operable or locally advanced breast cancer (BC). Breast Cancer Res Treat 2007, 106(Suppl 1):abstract 5055.

32. Greil R, Moik M, Reitsamer R, Ressler S, Stoll M, Namberger K, Menzel C, Mlineritsch B: Capecitabine + docetaxel + bevacizumab as neoadjuvant therapy for invasive breast cancer: results of a phase II pilot study. Breast Cancer Res Treat 2007, 106(Suppl 1):abstract 4064.

33. Balduzzi A, Montagna E, Bagnardi V, Torrisi R, Mancuso P, Scarano E, Viale G, Veronesi P, Cardillo A, Orlando L, Goldhirsch A, Colleoni M: Infusional fluorouracil, epirubicin, and cisplatin followed by weekly paclitaxel plus bevacizumab in locally advanced breast cancer with unfavourable prognostic features. Anticancer Drugs 2009, 20:197-203.

34. Wedam SB, Low JA, Yang SX, Chow CK, Choyke P, Danforth D, Hewitt SM, Berman A, Steinberg SM, Liewehr DJ, Plehn J, Doshi A, Thomasson D, McCarthy N, Koeppen H, Sherman M, Zujewski J, Camphausen K, Chen H, Swain SM: Antiangiogenic and antitumor effects of bevacizumab in patients with inflammatory and locally advanced breast cancer. J Clin Oncol 2006, 24:769-777.

35. Lyons JA, Silverman P, Remick S, Chen H, Leeming R, Shenk R, Fu P, Dumadag L, Escuro K, Overmoyer B: Toxicity results and early outcome data on a randomized phase II study of docetaxel \pm bevacizumab for locally advanced, unresectable breast cancer. J Clin Oncol 2006, 24(18S): abstract 3049

36. Raefsky E, Castillo R, Lahity A, Thompson DS, Hanson S, Meng C, Knauer D, Trieu V, Desai N, Yardley DA: Phase II study of neoadjuvant bevacizumab and trastuzumab administrated with albumin-bound paclitaxel (nab paclitaxel) and carboplatin in HER2+ locally advanced breast cancer. J Clin Oncol 2008, 26(May 20 Suppl):abstract 627.

37. Locatelli MA, Curigliano G, Fumagalli L, Ghisini R, Mancuso P, Bertolini F, Viale G, Lunghi L, Goldhirsch A: Bevacizumab and oral chemotherapy for patients with lymphangitis breast cancer: a phase II randomized study of bevacizumab with sequential versus concurrent oral vinorelbine plus capecitabine. J Clin Oncol 2009, 27(15S):abstract 1031.

38. Torrisi R, Bagnardi V, Cardillo A, Bertolini F, Scarano E, Orlando L, Mancuso P, Luini A, Calleri A, Viale G, Goldhirsch A, Colleoni M: Preoperative bevacizumab combined with letrozole and chemotherapy in locally advanced ER- and/or PgR-positive breast cancer: clinical and biological activity. Br J Cancer 2008, 99:1564-1571.

39. Forero-Torres A, Galleshaw J, Jones C, Percent I, Nabell L, Carpenter J, Falkson C, Krontiras H, Bland K, De Los Santos J, Saleh MN: A pilot openlabel trial of preoperative (neoadjuvant) letrozole in combination with bevacizumab in postmenopausal women with newly diagnosed operable breast cancer. J Clin Oncol 2008, 26(May 20 Suppl):abstract 652

40. Miller KD, O'Neill A, Perez EA, Seidman AD, Sledge GW: Phase II feasibility trial incorporating bevacizumab into dose-dense doxorubicin and cyclophosphamide followed by paclitaxel in patients with lymph nodepositive breast cancer: a trial of the Eastern Cooperative Oncology Group (E2104). J Clin Oncol 2008, 26(May 20 Suppl):abstract 520.

41. Hart LL, Badarinath S, Waterhouse DM, Daniel B, Raimondo D, Burris HA, Yardley DA: A multicenter study of 3 docetaxel regimens with bevacizumab as adjuvant therapy for breast cancer (BC): preliminary results. J Clin Oncol 2008, 26(May 20 Suppl):abstract 575.

42. Mayer EL, Miller KD, Rugo HS, Peppercorn JM, Carey LA, Ryabin N, Winer EP Burstein $\mathrm{HJ}$ : A pilot study of adjuvant bevacizumab after neoadjuvant 
chemotherapy for high-risk breast cancer. J Clin Oncol 2007, 25(18S): abstract 561.

43. Sanborn RE, Sandler A: The safety of bevacizumab. Expert Opin Drug Saf 2006, 5:289-301.

44. Holash J, Davis S, Papadopoulos N, Croll SD, Ho L, Russell M, Boland P, Leidich R, Hylton D, Burova E, Loffe E, Huang T, Radziejewski C, Bailey K, Fandl JP, Daly T, Wiegand SJ, Yancopoulos GD, Rudge JS: VEGF-trap: a VEGF blocker with potent antitumor effects. Proc Natl Acad Sci USA 2002, 99:11393-11398.

45. Hobday TJ, Rowland K, Dueck A, Northfelt D, Lingle W, Morton R, Fitch T, Nikcevich D, Perez EA: N0537: A North Central Cancer Group (NCCTG) phase II trial of VEGF trp in patients with metastatic breast cancer (MBC) previously treated with an anthracycline and/or a taxane. $J$ Clin Oncol 2008, 26(May 20 Suppl):abstract 164.

46. Chen Q, Manning CD, Millar H, McCabe FL, Ferrante C, Sharp C, ShahiedArruda L, Doshi P, Nakada MT, Anderson GM: CNTO 95, a fully human anti alphav integrin antibody, inhibits cell signaling, migration, invasion, and spontaneous metastasis of human breast cancer cell lines. Clin Exp Metastasis 2008, 25:139-148.

47. Fischer $C$, Jonckx B, Mazzone M, Zacchigna S, Loges S, Pattarini L, Chorianopoulos E, Liesenborghs L, Kock M, De Mol M, Autiero M, Wyns S, Plaisance S, Moons L, van Rooijen N, Giacca M, Stassen JM, Dewerchin M, Collen D, Carmelit P: Anti-PIGF inhibits growth of VEGF(R)-inhibitorresistant tumors without affecting healthy vessels. Cell 2007, 131:463-475.

48. Chow LQM, Eckhardt SG: Sunitinib: from rational design to clinical efficacy. J Clin Oncol 2007, 25:884-896.

49. Burstein HJ, Elias AD, Rugo HS, Cobleigh MA, Wolff AC, Eisenberg PD, Lehman M, Adams BJ, Bello CL, DePrimo SE, Baum CM, Miller KD: Phase II study of sunitinib malate, an oral multitargeted receptor tyrosine kinase inhibitor, in patients with metastatic breast cancer previously treated with an anthracycline and a taxane. J Clin Oncol 2008, 26:1810-1816.

50. Lyandres J, Melisko M, Moasser M, Goga A, Park JW, Rugo HS: Phase I study of sunitinib in combination with metronomic dosing of cyclophosphamide and methotrexate in patients with metastatic breast cancer. Cancer Res 2009, 69(Suppl 2):abstract 4119.

51. Gianni L, Cardoso F, Mariani G, Isaksson-Friman E, Besse-Hammer T, Vigano L, Verkh L, Rossi C, Giorgetti C, Bergh J: Exploratory evaluation of a sequential administration of docetaxel and sunitinib in women with advanced breast cancer. Breast Cancer Res Treat 2007, 106(Suppl 1): abstract 6079.

52. Kozloff MF, Chuang E, Roy J, Starr A, Gowland PA, Tarpey MJ, Collier M, Verk L, Miller K: A phase I study of sunitinib plus paclitaxel for first-line treatment af advanced breast cancer: preliminary results. Breast Cancer Res Treat 2007, 106(Suppl 1):abstract 6078.

53. Wildiers $\mathrm{H}$, Fontaine $\mathrm{C}$, Vuylsteke $\mathrm{P}$, Martens $\mathrm{M}$, Canon J-L, Wynendaele W, Focan C, Degreve J, Paridaens R: SUCON trial (SUnetinib CONsolidation therapy in metastatic breast cancer): a Belgian multicenter phase II randomized trial in Her2 negative metastatic breast cancer evaluating consolidation antiangiogenic therapy with sunitinib after objective response to taxane chemotherapy. Cancer Res 2009, 69(Suppl):abstract 203.

54. Bergh J, Greil R, Voytko N, Makhson A, Cortes J, Lortholary A, Huang X, Giorgetti C, Kern KA, Lichinitser M: Sunitinib (SU) in combination with docetaxel (D) versus $D$ alone for the first-line treatment of advanced breast cancer (ABC). J Clin Oncol 2010, 28(15S):abstract LBA1010.

55. Crown J, Dieras V, Staroslawska E, Yardley DA, Davidson N, Bachelot TD, Tassell TR, Huang X, Kern KA, Romieu G: Phase III trial of sunitinib (SU) in combination with capecitabine $(C)$ versus $C$ in previously treated advanced breast cancer (ABC). J Clin Oncol 2010, 28(15S):abstract LBA1011.

56. Barrios C, Liu MC, Lee SC, Vanlemmens L, Ferrero JM, Tabei T, Pivot $X$, Iwata H, Aogi K, Lugo-Quintana R, Harbeck N, Brickman MJ, Zhang K, Zhang K, Kern KA, Martin M: Phase III randomized trial of sunitinib versus capecitabine in patients with previously treated HER2-negative advanced breast cancer. Breast Cancer Res Treat 2010, 121:121-131.

57. Chu TF, Rupnick M, Kerkela R, Dallabrida SM, Zurakowski D, Nguyen L, Woulfe K, Pravda E, Cassiola F, Desai J, George S, Morgan JA, Harris DM, Ismail NS, Chen JH, Schoen FJ, van den Abbeele AD, Demetri GD, Force T, Chen MH: Cardiotoxicity associated with tyrosine kinase inhibitor sunitinib. Lancet 2007, 370:2011-2019.
58. Strumberg D: Preclinical and clinical development of the oral multikinase sorafenib in cancer treatment. Drugs Today (Barc) 2005, 41:773-784.

59. Bianchi GV, Loibl S, Zamagni C, Salvagni S, Raab G, Siena S, Laferriere N, Penña C, Lathia C, Bergamini L, Gianni L: Phase II multicenter, uncontrolled trial of sorafenib in patients with metastatic breast cancer. Anticancer Drugs 2009, 20:616-624.

60. Baselga J, Grupo Espanol de Estudio Tratamiento y Otras Estrategias Experimentales en Tumores Sólido, Roché H, Costa F, Getulio JMS, Pinczowski H, Ma EC, Cabral SF, Gomez P, van Eyll B: SOLTI-0701: a multinational double-blind, randomized phase $2 \mathrm{~b}$ study evaluating the efficacy and safety of sorafinib compared to placebo when administered in combination with capecitabine in patients with locally advanced or metastatic breast cancer (BC). Cancer Res 2009, 69(Suppl):abstract 45.

61. Gradishar WJ, Kaklamani V, Prasad TS, Lokanatha D, Raina V, Bondarde S, Jain M, Schwartzberg L: A double-blind, randomized, placebo-controlled, phase $2 \mathrm{~b}$ study evaluating the efficacy and safety of sorafenib (SOR) in combination with paclitaxel (PAC) as a first-line therapy in patients (pts) with locally recurrent or metastatic breast cancer. Cancer Res 2009, 69(Suppl):abstract 44.

62. Sonpavde G, Hudson TE: Pazopanib: a novel multitargeted tyrosine kinase inhibitor. Curr Oncol Rep 2007, 9:115-119.

63. Taylor SK, Chia S, Dent S, Clemons M, Grenci P, Wang L, Oza AM, Ivy P, Pritchard K, Leighl N: A phse II study of GW786034 (pazopanib) in patients with recurrent or metastatic invasive breast carcinoma: results after completion of stage I: a trial of the Princess Margaret Hospital Phase II Consortium. J Clin Oncol 2009, 27(15S):abstract 1133.

64. Wood JM, Bold G, Buchdunger E, Cozens R, Ferrari S, Frei J, Hofmann F, Mestan J, Mett H, O'Reilly T, Persohn E, Rösel J, Schnell C, Stover D, Theuer A, Towbin H, Wenger F, Woods-Cook K, Menrad A, Siemeister G, Schirner M, Thierauch KH, Schneider MR, Drevs J, Martiny-Baron G, Totzke F: PTK787/ZK 222584, a novel and potent inhibitor of vascular endothelial growth factor receptor tyrosine kinases, impairs vascular endothelial growth factor-induced responses and tumor growth after oral administration. Cancer Res 2000, 60:2178-2189.

65. Wedge SR, Ogilvie DJ, Dukes M, Kendrew J, Chester R, Jackson JA, Boffey SJ, Valentine PJ, Curwen JO, Musgrove HL, Graham GA, Hughes GD, Thomas AP, Stokes ES, Curry B, Richmond GH Wadsworth PF, Bigley AL, Hennequin LF: ZD6474 inhibits vascular endothelial growth factor signaling, angiogenesis, and tumor growth following oral administration. Cancer Res 2002, 62:4645-4655.

66. Miller KD, Trigo JM, Wheeler C, Baarge A, Rowbottom J, Sledge G, Baselga J: A multicenter phase II trial of ZD6474, a vascular endothelial growth factor receptor-2 and epidermal growth factor receptor tyrosine kinase inhibitor, in patients with previously treated metastatic breast cancer. Clin Cancer Res 2005, 11:3369-3376.

67. Boér K, Láng I, Liombart-Cussac A, Andreasson I, Vivanco GL, Sanders N, Pover GM, Murray E: Vandetanib with docetaxel as second-line treatment for advanced breast cancer: a double-blind, placebo-controlled, randomized phase II study. Breast Cancer Res Treat 2007, 106(Suppl 1): abstract 6081.

68. Rosen LS, Kurzrock R, Mulay M, van Vugt A, Purdom M, Ng C, Silverman J, Koutsoukos A, Sun YN, Bass MB, Xu RY, Polverino A, Wiezorek JS, Chang DD, Benjamin R, Herbst RS: Safety, pharmacokinetics, and efficacy of AMG 706, an oral multikinase inhibitor, in patients with advanced solid tumors. J Clin Oncol 2007, 25:2369-2376.

69. de Boer R, White S, Mainwaring P, Koczwara B, Ye Y, Sun Y-N, Parson M, Braun A, Kotasek D: Safety and pharmacokinetics of motesanib diphosphate (AMG 706) with paclitaxel or doxorubicin for the treatment of locally recurrent, unresectable or metastatic breast cancer. Breast Cancer Res Treat 2007, 106(Suppl 1):abstract 6074.

70. Choueiri TK: Axitinib, a novel anti-angiogenic drug with promising activity in various solid tumors. Curr Opin Investig Drugs 2008, 9:658-671.

71. Rugo HS, Stopeck A, Joy AA, Chan S, Verma S, Lluch A, Liau KF, Kim S, Bycott P, Soulieres D: A randomized, double-blind phase II study of the oral tyrosine kinase inhibitor (TKI) axitinib (AG-013736) in combination with docetaxel $(\mathrm{DOC})$ compared to DOC plus placebo (PL) in metastatic breast cancer (MBC). J Clin Oncol 2007, 25(18S):abstract 1003.

72. Nickoloff BJ, Osborne BA, Miele L: Notch signalling as a therapeutic target in cancer: a new approach to the development of cell fate modifying agents. Oncogene 2003, 22:6598-6608. 
73. Herbst RS, Hong D, Chap L, Kurzrock R, Jackson E, Silverman JM, Rasmussen E, Sun YN, Zhong D, Hwang YC, Evelhoch JL, Oliner JD, Le N, Rosen LS: Safety, pharmacokinetics, and antitumor activity of AMG 386, a selective angiopoietin inhibitor, in adult patients with advanced tumors. J Clin Oncol 2009, 27:3557-3565.

74. Fasola A, Sessa C: mTOR inhibitors in the treatment of cancer. Expert Opin 2008, 17:1717-1734

75. Del Bufalo D, Ciuffreda L, Trisciuoglio D, Desideri M, Cognetti F, Zupi G, Milella M: Angiogenic potential of the mammalian target of rapamycin inhibitor temsirolimus. Cancer Res 2006, 66:5549-5554.

76. Yu K, Toral-Barza L, Discafani C, Zhang WG, Skotnicki J, Frost P, Gibbons JJ: mTOR, a novel target in breast cancer: the effect of CCI 779, an mTOR inhibitor, in preclinical models of breast cancer. Endocr Relat Cancer 2001, 8:249-258.

77. Beuvink I, Boulay A, Fumagalli S, Zilbermann F, Ruetz S, O'Reilly T, Natt F, Hall J, Lane HA, Thomas G: The mTOR inhibitor RAD001 sensitizes tumor cells to DNA-damaged induced apoptosis through inhibition of p21 translation. Cell 2005, 120:747-759.

78. Chan S, Scheulen ME, Johnston S, Mross K, Cardosa F, Dittrich C, Eiermann $W$, Hess D, Morant R, Semiglazov V, Borner M, Salzberg M, Ostapenko V, Illiger HJ, Behringer D, Bardy-Bouxin N, Boni J, Kong S, Cincotta M, Moore L: Phase II study of temsirolimus (CCl-779), a novel inhibitor of mTOR, in heavily pretreated patients with locally advanced or metastatic breast cancer. J Clin Oncol 2005, 23:5314-5322.

79. Ellard S, Clemons M, Gelmon KA, Norris B, Kennrcke H, Chia S, Pritchard K, Eisen A, Vandenberg T, Taylor M, Sauerbrei E, Mishaeli M, Huntsman D, Walsh W, Olivo M, McIntosh L, Seymour L: Randomized phase II study comparing two schedules of everolimus in patients with recurrent/ metastatic breast cancer: NCIC Clinical Trial Group IND.163. J Clin Oncol 2009, 27:4536-4541.

80. O'Reilly KE, Rojo F, She Q-B, Solit D, Mills GB, Smith D, Lane H, Hofmann F, Hicklin DJ, Ludwig DL, Baselga J, Rosen N: mTOR induces upstream receptor tyrosine kinase signalling and activates Akt. Cancer Res 2006, 66:1500-1508.

81. Moulder SL, Rivera E, Ensor J, Gonzales-Angulo A, Christofanilli M, Booser D, Giordano S, Brewster A, Hortobagyi GN, Tran H: Phase I trial of escalating doses of weekly everolimus (RAD001) in combination with docetaxel for the treatment of metastatic breast cancer (MBC). J Clin Oncol 2009, 27(15S):abstract 1066.

82. Mayer IA, Burris HA, Bendell JC, Means-Powell J, Arteaga CL, Shyr Y, Pietenpol JA: A phase lb trial of RAD001, an mTOR inhibitor, with weekly cisplatin and paclitaxel in patients with HER2-negative metastatic breast cancer. Cancer Res 2009, 69(Suppl):abstract 3093.

83. Carpenter JT, Roche H, Campone M, Colomer R, Jagiello-Gruszfeld A, Moore L, D'Amore M, Kong S, Boni J, Baselga J: Randomized 3-arm, phase 2 study of temsirolimus (CCl-779) in combination with letrozole in postmenopausal women with locally advanced or metastatic breast cancer. J Clin Oncol 2007, 23(16S):abstract 564.

84. Chow LWC, Sun Y, Jassem J, Baselga J, Hayes DF, Wolff AC, Hachemi S, Cincotta M, Yu BW, Kong S, Moore L: Phase 3 study of temsirolimus with letrozole or letrozole alone in postmenopausal women with locally advanced or metastatic breast cancer. Breast Cancer Res Treat 2006, 100(Suppl 1):abstract 6091.

85. Macaskill EJ, Bartlett JMS, White S, Renshaw L, Campbell FM, Young O, Stumm M, Faratian D, Thomas J, Barber MD, Dixon JM: The mammalian target of rapamycin inhibitor RAD001 (everolimus) in postmenopausal women with early breast cancer: results of a phase II pre-operative trial. Breast Cancer Res Treat 2007, 106(Suppl 1):abstract 6092.

86. Baselga J, Semiglazow V, van Dam PA, Manikhas A, Bellet M, Mayordomo J, Campone M, Kubista E, Greil R, Bianchi G, Steinseifer J, Molloy B, Tokaji E, Gardner H, Phillips P, Stumm M, Lane HA, Dixon JM, Jonat W, Rugo HS: Phase II randomized study of neoadjuvant everolimus plus letrozole compared with placebo plus letrozole in patients with estrogen receptor-positive breast cancer. J Clin Oncol 2009, 27:2630-2637.

87. Tortora G, Ciardiello F, Gasparini G: Combined targeting of EGFRdependent and VEGF-dependent pathways: rationale, preclinical studies and clinical applications. Nat Clin Pract Oncol 2008, 5:521-530.

88. Fountzilas G, Skarlos D, Wirtz RM, Dafni U, Stropp U, Pectasides D, Papakostas P, Markopoulos C, Karapanagiotis K, Polichronis A, Timotheadou E, Grimani I, Samantas E, Kosmidis P, Kalogeras KT: Prognostic value of both HER-2 and VEGF-A mRNA over-expression in primary tumors of high-risk breast cancer patients. Breast Cancer Res Treat 2007, 106(Suppl 1):abstract 6007.

89. Hurvitz SA, Pegram MD, Lin L-S, Chan DS, Allen HJ, Dichmann RA, Hagenstad CT, Barstis J, Hermann RC, Hu EH, Moroose RL, Thomas SP, Vogel CL, Ryba N, Elashoff D, Slamon DJ: Final results of a phase II trial evaluating trastuzumab and bevacizumab as first line treatment of HER2-amplified advanced breast cancer. Cancer Res 2009, 69(Suppl): abstract 6094.

90. Dickler MN, Rugo HS, Eberle CA, Brogi E, Caravelli JF, Panageas KS, Boyd J, Yeh B, Lake DE, Dang CT, Gilewski TA, Bromberg JF, Seidman AD, D'Andrea GM, Moasser MM, Melisko M, Park JW, Dancey I, Norton L, Hudis CA: Phase II trial of erlotinib in combination with bevacizumab in patients with metastatic breast cancer. Clin Cancer Res 2008, 14:7878-7883.

91. Dickler M, Franco S, Stopeck A, Ma W, Nulsen B, Lyandres J, Melisko M, Lahiri S, Arbushites M, Koehler M, Rugo HS: Final results from a phase II evaluation of lapatinib (L) and bevacizumab (B) in HER2-overexpressing metastatic breast cancer. Cancer Res 2009, 69(Suppl 2):abstract 3133.

92. Blay J-Y, Lluch A, Gutierrez M, Martin MM, Kozloff MF, Prady C, Huang X, Chen C, Tassell V, Kern K, Verma S: Sunitinib (SU) in combination with trastuzumab ( $T$ ) for the treatment of advanced breast cancer (ABC): activity and safety results from a phase II. Cancer Res 2009, 69(Suppl): abstract 201

93. Dirix L, Canon J-L, Amadori D, Villa E, Aldrighetti D, Machiels J-P, Verkh L, Bouko Y, Kern K, Giorgetti C, Cardoso F: An exploratory study of sunitinib (SU) plus docetaxel (D) and trastuzumab (T) as first-line therapy for HER2+ advanced breast cancer (ABC). Cancer Res 2009, 69(Suppl):abstract 6088.

94. Slamon D, Gomez HL, Kabbinavar F, Amit O, Richie M, Pandite L, Goodman V: Randomized study of pazopanib - lapatinib vs. lapatinib alone in patients with HER2-positive advanced or metastatic breast cancer. J Clin Oncol 2008, 26(May 20 Suppl):abstract 1016.

95. O'Regan R, Andre F, Campone M, Naughton M, Manlius C, Pylvaenaeinen I, Sahmoud T, Hurvitz S: RAD001 (everolimus) in combination with weekly paclitaxel and trastuzumab in patients with HER-2-overexpressing metastatic breast cancer with prior resistance to trastuzumab: a multicenter phase I clinical trial. Cancer Res 2009, 69(Suppl 2):abstract 3119.

96. Yardley DA, Seiler M, Ray-Coquard I, Melichar B, Hart L, Dieras V, Barve M, Melnyk A, Dorer D, Turner CD: Ridaforolimus (AP23573; MK-8669) in combination with trastuzumab for patients with HER2-positive trastuzumab-refractory metastatic breast cancer: a multicenter phase ॥ trial. Cancer Res 2009, 69(Suppl):abstract 3091.

97. Mayer IA, Means-Powell J, Shyr Y, Arteaga CL: A phase Ib trial of erlotinib, an EGFR inhibitor, and everolimus (RAD001), an mTOR inhibitor, in patients with metastatic breast cancer. Cancer Res 2009, 69(Suppl): abstract 3094

98. Mayer EL, Dhakil S, Patel T, Sundaram S, Fabrian C, Kozloff M, Qamar R, Volterra F, Parmar H, Samant M, Burstein HJ: SABRE-B: an evaluation of paclitaxel and bevacizumab with or without sunitinib as first-line treatment of metastatic breast cancer. Ann Oncol 2010.

99. Falchook GS, Wheler JJ, Naing A, Hong DS, Moulder SL, Piha-Paul SA, $\mathrm{Ng} \mathrm{CS}$, Jackson E, Kurzrock R: A phase I study of bevacizumab in combination with sunitinib, sorafenib, and erlotinib plus cetuximab, and trastuzumab plus lapatinib. J Clin Oncol 2010, 28(15S):abstract 2512.

100. Yanagisawa M, Yorozu K, Kurasawa M, Nakano K, Furugaki K, Yamashita Y, Mori K, Fujimoto-Ouchi K: Bevacizumab improves the delivery and efficacy of paclitaxel. Anticancer Drugs 2010, 21:687-694.

101. Dempke WCM, Heinemann V: Resistance to EGF-R (erb-1) and VRGF-r modulating agents. Eur J Cancer 2009, 45:1117-1128.

102. Bergers G, Hanahan D: Modes of resistance to anti-angiogenic therapy. Nat Rev Cancer 2008, 8:592-603.

103. Schneider BP, Wang M, Radovich M, Sledge GW, Badve S, Thor A, Flockhart DA, Hancock B, Davidsen N, Gralow J, Dickler M, Perez EA, Cobleigh M, Shenkier T, Edgerton S, Miller KD: ECOG 2100: Association of vascular endothelial growth factor and vascular endothelial growth factor receptor-2 genetic polymorphisms with outcome in a trial of paclitaxel compared with paclitaxel plus bevacizumab ECOG 2100. J Clin Oncol 2008, 26:4672-4678.

104. Paez-Ribes M, Allen E, Hudock J, Takeda T, Okuyama H, Vinals F, Inoue M, Bergers G, Hanahan D, Casanovas O: Antiangiogenic therapy elicits 
malignant progression of tumors to increased local invasion and distant metastasis. Cancer Cell 2009, 15:220-231.

105. Harbeck N, Chan A, ten Bokkel Huinink D, Chollet P, Fabiani C, Salvagni S, Pérez-Michel L, Scheeweiss A, Chlistalla A, Miles DW: No clinical evidence for increase in tumour malignant potential in patients with metastatic breast cancer treated with bevacizumab and docetaxel in the phase III AVADO study. Cancer Res 2009, 69(Suppl):abstract 6086.

106. Jain RK, Duda DG, Willett CG, Sahani DV, Zhu AX, Loeffler JS, Batchelor TT, Sorensen AG: Biomarkers of response and resistance to antiangiogenic therapy. Nat Rev Clin Oncol 2009, 6:327-338.

107. Murukesh N, Dive C, Jayson GC: Biomarkers of angiogenesis and their role in the development of VEGF inhibitors. Br J Cancer 2010, 102:8-18.

108. Sessa C, Guibal A, Del Comte G, Rüegg C: Biomarkers of angiogenesis for the development of antiangiogenic therapies in oncology: tools or decorations? Nat Clin Pract Oncol 2008, 5:378-391.

109. Marcus CD, Ladam-Marcus V, Cucu C, Bouché O, Lucas L, Hoeffel C: Imaging techniques to evaluate the response to treatment in oncology: current standards and perspectives. Crit Rev Oncol Hematol 2009, 72:217-238,

110. Fojo T, Grady C: How much is life worth: cetuximab, non-small cell lung cancer, and the $\$ 440$ billion question. J Natl Cancer Inst 2009, 101:1044-1048.

111. Duda DG, Ancukiewicz M, Jain RK: Biomarkers of antiangiogenic therapy: how do we move from candidate biomarkers to valid biomarkers? I Clin Oncol 2010, 28:183-185.

112. McArthur HL, Rugo H, Paulson M, Rourke M, Traina T, Panageas K, Steingart R, Dang C, Fornier M, Park J, Moasser M, Melisko M, Sugarman S, Norton L, Hudis CA, Dickler MN: Cardiac safety of adjuvant bevacizumab plus dose-dense doxorubicin/cyclophosphamide followed by nanoparticle albumin-bound paclitaxel in patients with early stage breast cancer. Breast Cancer Res Treat 2007, 106(Suppl 1):abstract 3065.

113. Isaacs C, Wilkinson M, Liu MC, Ottaviano Y, Chung G, Warren R, Jennifer EW, Cohen P, Smith KL, Novielli A, Castle J, Slack R: Phase II study of sorafenib with anastrozole to overcome resistance to aromatase inhibitors (Als) in patients with hormone receptor positive (ER/PR+) Al resistant metastatic breast cancer (MBC). Cancer Res 2009, 69(Suppl): abstract 3090.

doi:10.1186/bcr2642

Cite this article as: Nielsen et al: Antiangiogenic therapy for breast cancer. Breast Cancer Research 2010 12:209.

\section{Submit your next manuscript to BioMed Central and take full advantage of:}

- Convenient online submission

- Thorough peer review

- No space constraints or color figure charges

- Immediate publication on acceptance

- Inclusion in PubMed, CAS, Scopus and Google Scholar

- Research which is freely available for redistribution 